\title{
Tillage erosion: a review of controlling factors and implications for soil quality
}

\author{
K. Van Oost, G. Govers, S. de Alba \\ and T. A. Quine
}

\begin{abstract}
Tillage erosion has been identified as an in nportantglobal soil degradation process that has to be accounted for when assessing the erosional irnpacts on soil productivity, environmental quality or landscape evolution. In this paper, we present a summary of available data describing tillage erosion. This provides insights in the controlling factors determining soil redistribution rates and patterns by tillage for various irnplements used in both mechanized and non-mechanized agriculture. Variations in tillage depth and tillage direction cause the largest variations in soil redistribution rates, although other factors, such as tillage speed and irnplement characteristics, also play an important role. In general, decreasing tillage depth and ploughing along the contour lines substantially reduce tillage erosion rates and can be considered as effective soil conservation strategies. Implement erosivities reported in literature, characterized by the tillage transport coefficient, are very consistent and range in the order of $400-800 \mathrm{~kg} \mathrm{~m}^{-1} \mathrm{yr}^{-1}$ and $70-260 \mathrm{~kg} \mathrm{~m}^{-1} \mathrm{yr}^{-1}$ for mechanized and nonmechanized agriculture, respectively. Comparison of tillage erosion rates with water erosion rates using a global data set indicates that tillage erosion rates are at least in the same order of magnitude or higher than water erosion rates, in almost all cases. Finally, we discuss how tillage erosion increases the spatial variability of soil properties and affects soil nutrient cycling. Considering the widespread use of tillage practices, the high redistribution rates associated with the process and its direct effect on soil properties, it is clear that tillage erosion should be considered in soil landscape studies.
\end{abstract}

Key words: soil erosion, soil quality, tillage erosion, ${ }^{137} \mathrm{Cs}$.

\section{Introduction}

Unlike water and wind erosion, whose effects are often dramatic and can be easily identified in the landscape, the extent and severity of tillage erosion only become apparent after several decades of tillage through variations in soil properties (the appearance of subsoil at the surface) and the development of tillage-related 
landforms like tillage banks. It is therefore no surprise that attention of soil erosion research during the last decades has focused heavily on sheet and rill erosion (Govers et al., 1999). However, a large body of information, from a wide range of research domains, is available in literature that indicates that tillage is responsible for the movement of soil material. These papers focus on the investigation of tillage effects on (i) the dispersion of weed seeds (Marshall and Hopkins, 1990; Marshall and Brain, 1999), (ii) the incorporation of fertilizers or crop residues (Staricka et al., 1990; 1991), (iii) the dispersion of soil amendments or constituents in long-term field experiments (Sibbesen et al., 1985; 2000; Sibbesen and Andersen, 1985; Sibbesen, 1986), (iv) the redistribution of archaeological artefacts in agricultural land (Reynolds, 1988; Yorstonet al., $1990)$ or ( $v$ ) on the design and performance of tillage implements (Reaves and Schafer, 1975; Kermis, 1978). Although these studies demonstrated the existence of substantial soil translocation by tillage operations, the identification of tillage erosion was hampere by the fact that they were conducted on level land, so that the assessment of tillage erosion rates and patterns was not possible.

Mech and Free (1942) were the first to carry out systematic tillage erosion experiments with tillage implements common for that time. They concluded that soil movement was far from insignificant and its intensity was related to slope gradient. Follow-up experiments by Petersen $(1960)$ and by Weinblum and Stekelmacher (1963) corroborated these findings but were never published in international literature. In addition to this, a considerable amount of qualitative information on the importance of tillage erosion was published. This was mainly related to the formation of lynchets or soil banks (Papendick and Miller, 1977) and the development of terraces (Aase and Pikul, 1995). Other papers pointing to the importance of tillage erosion were: Dejong et al. (1983); Kachanoski et al. (1985); Revel and Guiresse (1995). Some authors relate the variability in crop yield and soil quality to the possible effects of tillage erosion. Miller et $\boldsymbol{a l}$. (1988) and Moulin et $\boldsymbol{a l}$. (1994) found a significantly lower soil organic matter content and crop yield on slope convexities. Also Verity and Anderson (1990) observed lower grain yields on upper convex slope positions.

Researchers working in relative isolation in eastern Europe have since long recognised soil tillage as an important erosion process on agricultural land (Khachatryan, 1985). Various experimental studies of tillage translocation and tillage erosion were made (Czyzyk, 1955; Kiburys, 1989; Martini, 2005), including investigations on terrace formation dynamics due to tillage (Lobotka, 1955).

The development of the ${ }^{137} \mathrm{Cs}$ technique has contributed significantly to the recognition of the tillage erosion process. The technique allows to assess the total soil redistribution rates and patterns in a landscape over a timescale of several decades, independent of the process causing it. Early studies whereby the ${ }^{137} \mathrm{Cs}$ technique was used showe a rather unexpected spatial pattern of soil erosion: highest soil losses occurred on convexities and deposition in hollows (eg, Dejong et al., 1983; Quine and Walling, 1991). This spatial pattern did not agree with the pattern that can be expected to result from water erosion. Furthermore, comparison of ${ }^{137} \mathrm{Cs}$ derived erosion rates and patterns with results of water erosion models often showed poor agreement (Dejong et al., 1986; Soileau et al., 1990; Bernard and Laverdiere, 1992). Other studies supplied additional evidence that soil erosion occurred on unexpected locations on sloping agricultural land, eg, studies of soil profile truncation (eg, Daniels et al. , 1985; Verity and Anderson, 1990); of spatial variation in crop productivity (eg. Miller et al., 1988; Cao et al., 1994) or whereby elevation differences between agricultural land and adjacent non-cultivated land were use to assess soil erosion (Govers et al., 1993).

It was only in the late 1980s (eg, Kiburys, 1989) and early 1990s (eg, Lindstrom et al., 
1992; Gøvers et al., 1994; L•bb et al., 1995) that systernatic studies of tillage translocation and erosion were rnade. These experimental studies showed that tillage results in a net movement of søil, leading to a net soil loss (tillage erosion) from convex landscape positiøns and a net sil gain (tillage deposition) in concave landscape positions. Later, studies combininghigh-res lution ${ }^{137} \mathrm{Cs}$ data with ge•-

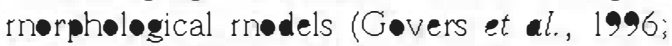
Quine et $\boldsymbol{a} l$, , 1997) and additional tillage erosion experiments (eg, Guiresse and Revel, 1995; P•esen et al., 1997; L•bb et al., 1999; Van Muysen et al, 1999, Montgomery et al, 1999; Quine et al, 1999a) provided further evidence for substantial tillage induced soil erosion and deposition under mechanized agriculture.

At present, there are over $\mathbf{8 0}$ research papers in the literature that specifically deal with tillage erosion (Figure 1). Initially, these studies focused on the experimental identification of controlling variables and the assessment of tillage erosion rates (rnostly using ${ }^{137} \mathrm{Cs}$ as a marker of soil movement) M॰re recently, tillage erosion effects on sil quality and roductivity in various agr-ecoløical environments have been documented ( $\mathrm{Li}$ and Lindstr•m, 2001; K॰smas et al., 2001; de Alba, 2001; Quine and Zhang, 2002; da Silva and Alexandre, 2004, Li et al,, 2004, Heckrathet $\mathbf{l}$., 2005) and tillage er sim simulation models have been developed (Gøvers et al., 1996; Van Oost et al., 2000b; 2003b; de Alba, 2003, Schøorl et al., 2004; Quine and Zhang, 2004c). While early studies on tillage erosion strongly focused on mechanized agriculture, recent studies have shown that substantial tillage er $\bullet n$ als $\bullet$ ccurs in level-ping countries with animal or man powered tillage t॰ls, especially when tillage is performed in dissected landscapes on steep

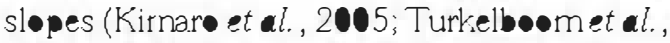
1997; 1999, Thapa et al, , 1999a; 1999b; Quine et $\boldsymbol{a l}$, 1999b; 1999c; Nyssen et al., 2000; Dercon et al., 2003; Zhang et al., 2004b) Consequently, tillage erosion is now rec $\bullet$ nized as an important gløbal s il degradation precess that has to be accunted for when assessing the ersional impacts on søil productivity (eg, Heckrathet al., 2005), environmental

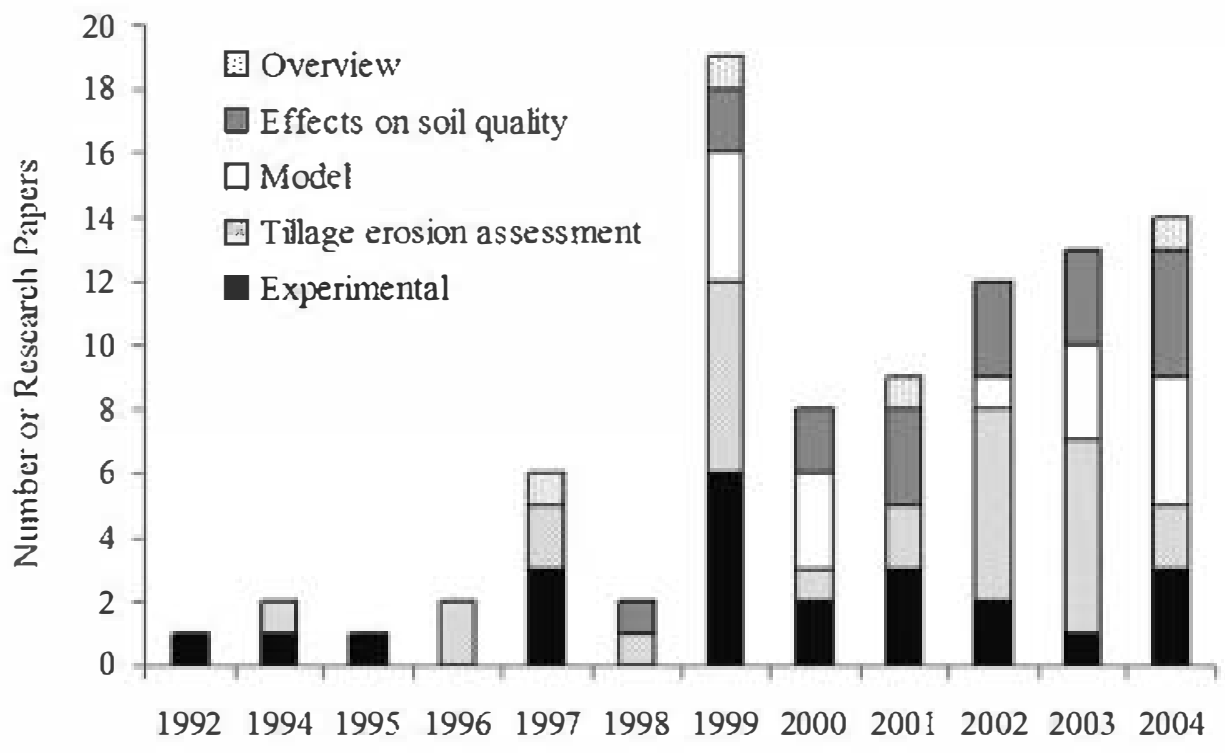

Figure 1 Temporal evelution and typology of tillage erosion research papers in literature

Source: Web of Science. 
quality (eg, Lal, 2001) or landscape evolution (eg, Quine et al., 1997).

Although a large body of information on tillage erosion is now available, attempts to identify the major controls on the process and to quantify the importance of tillage erosion in the total soil redistribution on arable lands are very rare. This article presents the principles of tillage erosion, reviews estimates of controlling variables, describes strategies and practical considerations in soil conservation strategies, and assesses the overall importance of tillage erosion.

\section{The principle of tillage erosion}

\section{Definition}

Whenever soil is cultivated, tillage translocation, which is the displacement of the cultivation layer, takes place. This translocation is expressed as mass of soil moved by tillage in a specific direction per meter width. Translocation can also be expressed as a depth-averaged length, ie, the distance the till-layer is translocated. Experimental studies have shown that slope gradient has a dominant influence on soil translocation during tillage operations, as it is a gravity-driven process (Lindstrom et al., 1992; Govers et al., 1994; Lobb et al., 1995; Poesen et al., 1997; Van Muysen et al., 1999; Quine et al., 1999a). The basic nature of this process is illustrated in Figure 2. Generally, soil translocation rates are highest when tillage is performed in the downslope direction on steep slopes. Translocation rates decrease gradually when moving to less steep slopes and are lowest when tillage is performed in the upslope direction on steep slopes. Consequently,

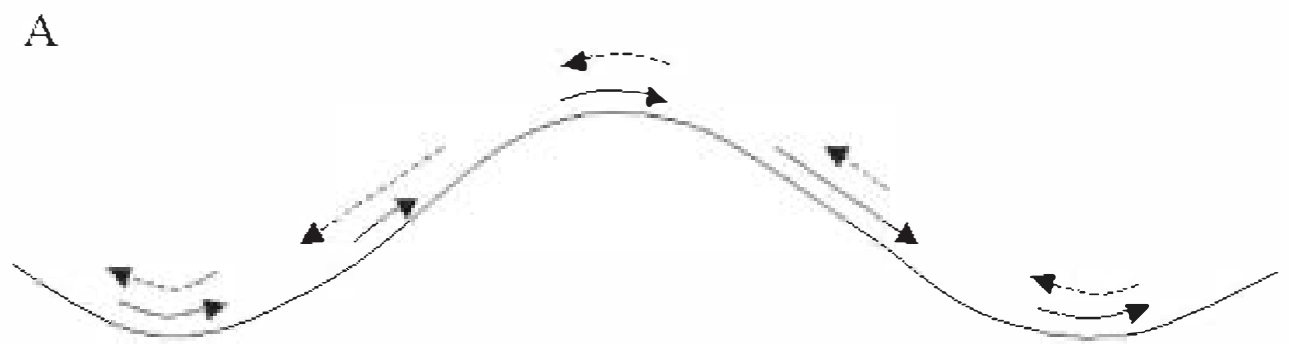

B

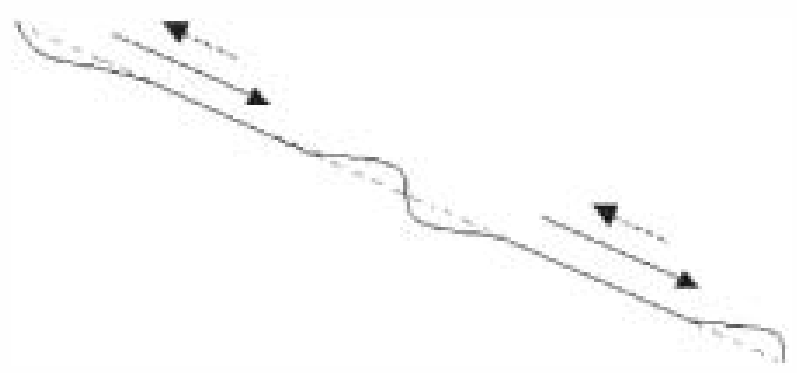

Figure 2 Principle of tillage erosion. (A) Variability of soil translocation in a hilly landscape. Soil translocation by tillage will result in soil loss on convex slope positions because there is an increase in slope gradient. Conversely, deposition takes place in concave slope positions. (B) In dissected landscapes (field boundaries, grass strips, terraces), tillage leads to soil loss on the uppermost portion of the slope segment and deposition occurs in lower portions, leading to the formation of soil banks. The lengths of the arrows reflect the magnitude of the process 
soil translocation by tillage varies within landscapes and a net movement of soil occurs on sloping land. For example, the downslope soil movement after a downslope tillage operation, is not fully compensated for by complementary upslope tillage operation, leading to a net downslope movement of soil.

Various definitions for tillage erosion are given in literature. Lindstrom et al. (2001) define it as 'the net movement of soil downslope through the action of mechanical implements'; while Lobb et al. (1999) use the definition "the net downslope translocation of soil material by tillage'. Lobb et al. (1995) provide a broad definition: 'the loss and accumulation of soil resulting from the variable translocation of soil by tillage'. Here, both component of the erosion process, ie, the erosion of soil material at specific landscape positions (tillage erosion) as well as the subsequent deposition of this eroded material at other positions (tillage deposition), are explicitly denoted.

\section{Patterns and field evidence of tillage erosion}

Soil translocation by tillage will result in soil loss on convex slope positions such as crests and shoulder slopes because there is an increase in slope gradient, thus an increase in soil translocation rate. Conversely, soil deposition will take place in concave slope positions. The spatial signatures of tillage erosion differ fundamentally from those of water erosion: soil loss by tillage will be most intense on landscape positions where water erosion is minimal (ie, on convexities and near upslope field boundaries) while areas of soil accumulation by tillage are often areas where water erosion is maximal (ie, hollows) (see Figure 3 for illustration). This has also implications for contemporary landform evolution on agricultural land: while continuing water erosion leads to increased incisions in concavities and a gradual increase in slope angle on convex slopes, tillage erosion will smoothen the landscape and reduce slope angles by moving soil from convexities to concavities.
Tillage erosion can be evidenced from differences in soil properties along a hillslope. Intensive tillage erosion results in substantial soil truncation and within field redistribution of soil and soil constituents. Continuing removal of topsoil and the subsequent lowering of the plough layer on convexities lead to the incorporation of nutrient-depleted subsoil material in the plough layer. At the same time, tillage accumulates soil at concavities where a dee soil enriched in nutrients develops. In areas with undulating topography, the appearance of subsoil material is indicative for tillage erosion (Figure 4).

Field boundaries represent physical barriers that interrupt soil flux by tillage (Papendick and Miller, 1977; Dabney et al., 1999; Van Oost et al., 2000a). These lines of zero flux produce a net soil accumulation on the upslope side or a net soil loss on the lower slope side. When a cross-slope boundary between fields is located at mid-slope positions, opposite balances of net soil loss or soil gain take place on the two sides of the boundary with the consequent formation of a linear ste, ie, lynchet or soil bank, along the boundary. The formation of soil banks due to tillage erosion is illustrated in Figure 5. Two types of tillage erosion should therefore be considered when analysing tillage erosion rates: (i) tillage erosion due to a change in slope (topography-based tillage erosion) and (ii) tillage erosion due to the effect of field boundaries (field boundary tillage erosion). It is clear that field boundary tillage erosion is important in dissected landscapes where tillage is conducted on small fields (eg, terrace agriculture in mountainous areas (Dercon et al. , 2003), whereas topographical tillage erosion is likely to be dominant in areas of mechanized agriculture which are associated with large fields (Van Oost et al., 2000a).

\section{Equations describing tillage transloc ation and erosion}

The most widespread used tillage model in experimental and modelling studies is based 


\section{Tillage Erosion}

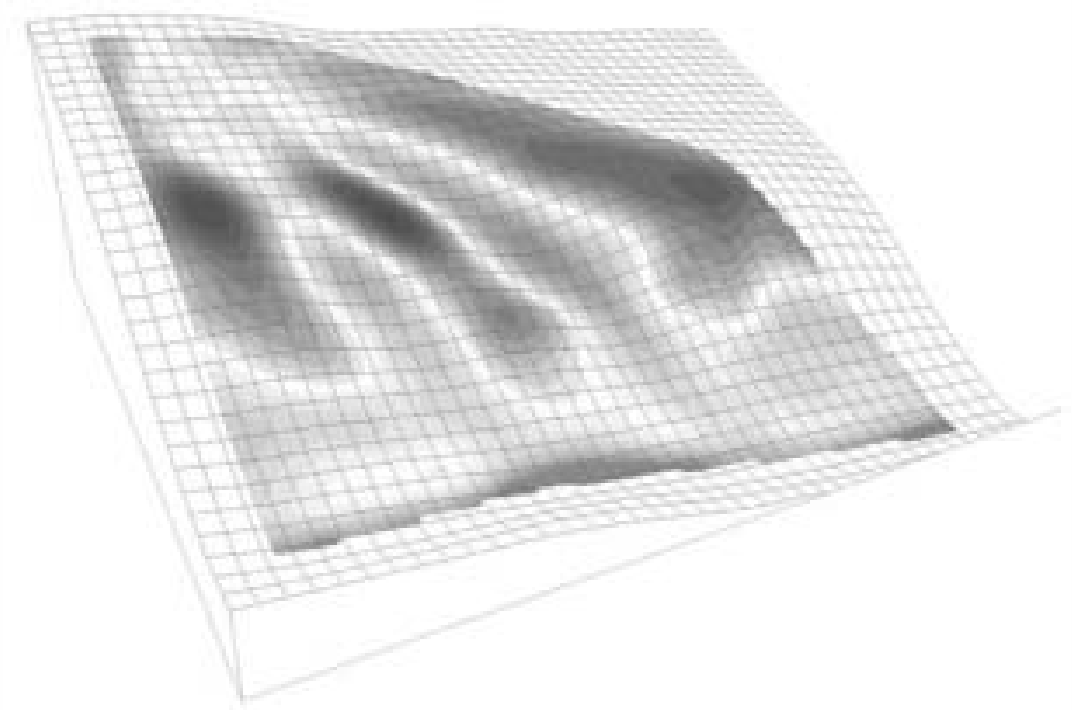

\section{Erosion}

\section{Water Erosion}

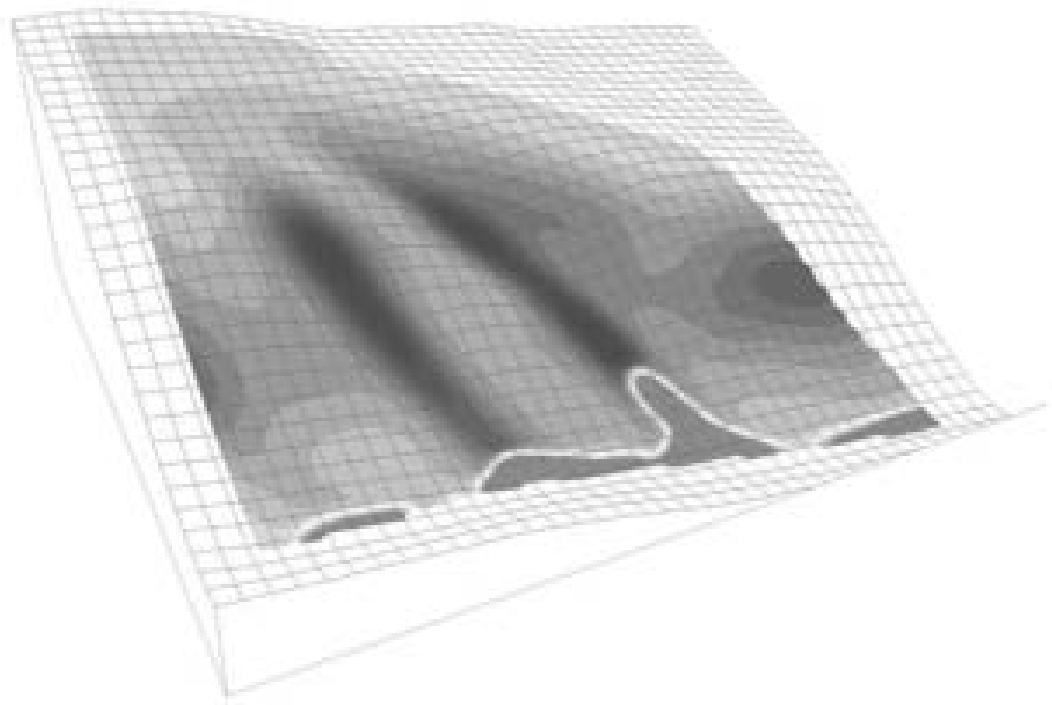

\section{Deposition}

Figure 3 Typical spatial patterns of tillage and water eresion simulated with the Wa TEM model (Van Oost et $1 ., 2000 \mathrm{a}$ ). Cell size is $6 \times 6 \mathrm{~m}$. Height difference between top and bottom of the field is approximately $12 \mathrm{~m}$

on the rnodel proposed by Govers et al. (1994). Here, tillage erosion is considered as a diffusion type process using the following reasoning. The rate of soil translocation in the direction of tillage, $Q_{s}\left(\mathrm{kgm}^{-1}\right)$, can be calculated as:

$$
Q_{s}=\rho_{b} \bar{d} D
$$




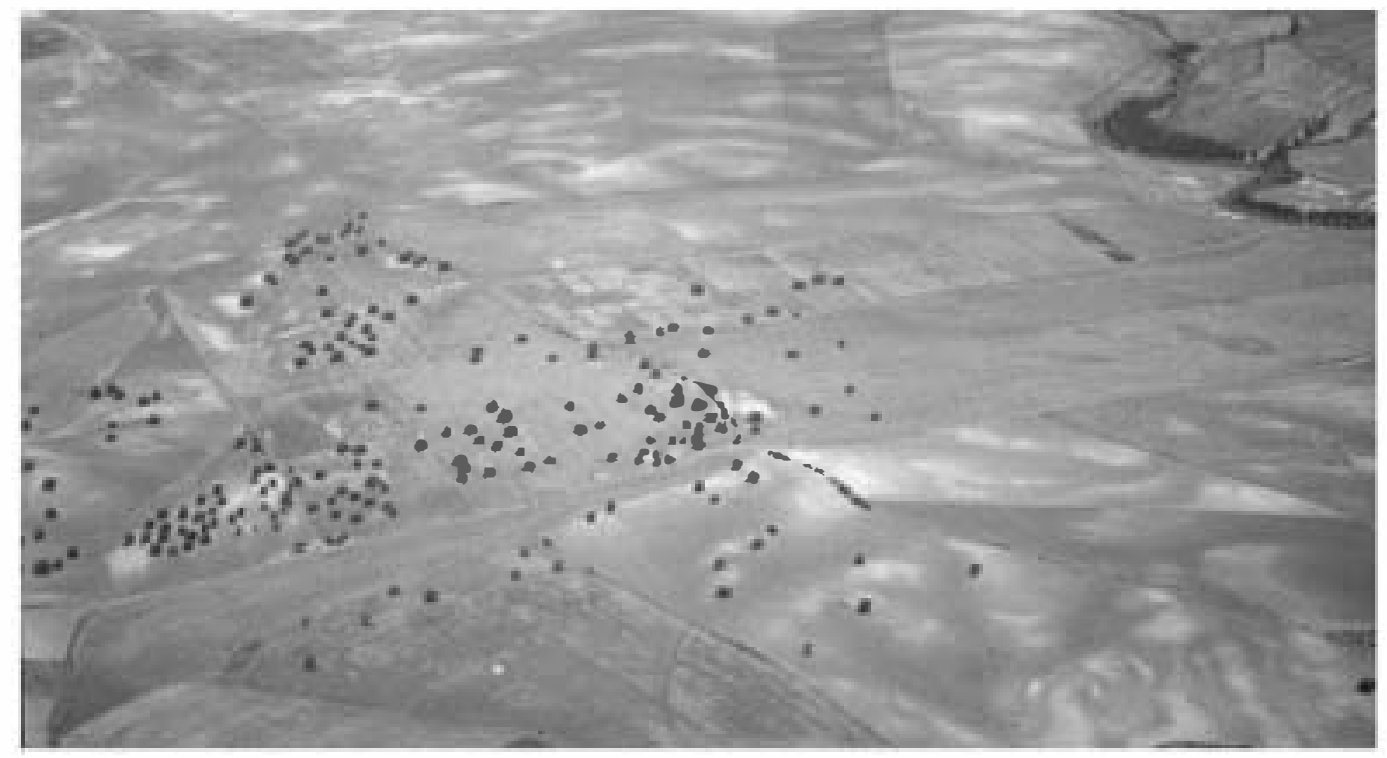

Figure 4 Typical spatial variability of søils in agricultural landscapes of rolling topography. In the picture, truncate søil profiles (of clear colour due to the presence of calcic material from an original subsurface soil hørizon) are predominant in the upper part of slopes and convexities and are indicatirye for tillage erosion (Castilla-La Mancha, Central Spain)

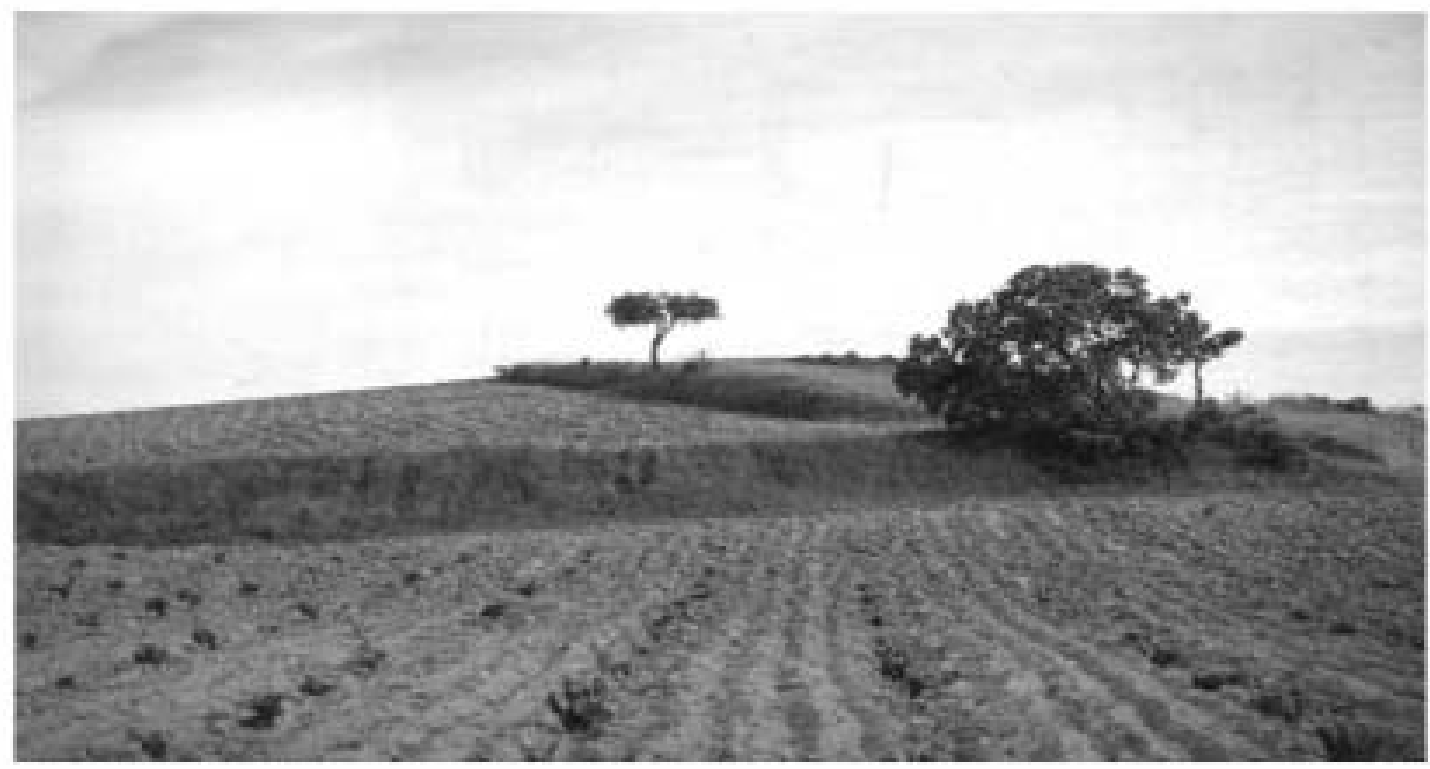

Figure 5 Field boundaries represent a physical barrier for søil transport by tillage. Søil accumulates at the upslope side while severe truncation takes place at the downslope

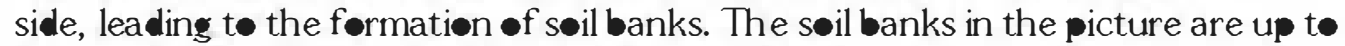
$1.6 \mathrm{~m}$ in height (Castilla-La Mancha, Central Spain) 
where $\boldsymbol{\rho}_{\boldsymbol{b}}$ is the soil bulk density $\left(\mathrm{kg} \mathrm{m}^{-3}\right), \bar{d}$ is the average soil translocation distance in the direction of tillage $(\mathrm{m})$, and $\boldsymbol{D}$ is the tillage depth $(\mathrm{m})$. Tillage experiments have found mean translocation distances as a result of a single tillage operation to be linearly, and inversely, related to slope (Govers et al., 1994):

$$
\bar{d}=\boldsymbol{a}+b S
$$

where $S$ is the slope tangent (positive u slope; negative downslope), and and $b$ are regression constants. Assuming opposing directions in successive tillage operations and that uphill slopes are designated as positive slope and downhill slopes are designated as negative slopes, the average net downslope soil translocation $\bar{d}_{n}$ per tillage operation may be expressed as

$$
\bar{d}_{s}=\frac{(\boldsymbol{a}+b S)-(\boldsymbol{a}-b S)}{2}=b S
$$

and the net lownslope rate of soil translocation after the two tillage operations will be:

$$
Q_{t, *}=D p_{b} b S
$$

Using the continuity equation for sediment movement on a hillslope and assuming the $\mathrm{x}$-axis to be positively oriented in the downslope direction, the tillage erosion or accumulation rate may then written as:

$$
E=-\frac{\partial Q}{\partial x}=-D \rho_{b} b \frac{\partial h_{1}}{\partial x}=k_{\mathrm{s}} \frac{\partial^{2} h}{\partial \mathrm{x}^{2}}
$$

where $h$ is the height at a given point of the hillslope and $k_{t i l}\left(=-\boldsymbol{D}_{\boldsymbol{p}_{b}} b\right)$ is a constant. This means that the rate of tillage erosion may be characterize by (i) a proportionality factor, $k_{t i l}$, which is referre to as the tillage transport coefficient, and (ii) the rate of change in slope in the direction of tillage. The tillage transport coefficient is an expression of tillage erosivity and permits the comparison of different tillage implements.

It is important to note that this diffusiontype model of tillage translocation and erosion is limite by the following necessary assumptions: (i) tillage depth and soil bulk density do not vary in space, (ii) tillage soil translocation can be expresse as a linear, univariate function of the slope gradient and (iii) tillage is conducted in opposing directions. However, the latter assumption is not necessary when estimating topography-based tillageerosion. In this case, the tillage transport coeficient is independent of the tillage direction applied, ie, it can be use to estimate erosion rates for alternating up- and downslope tillage operations or consecutive up- or lownslope operations.

\section{Factors controlling tillage translocation and erosion}

The process of tillage erosion can be seen as a function of the erosivity of a given tillage operation $\left(T_{E}\right)$ and the erodibility of the cultivated landscape $\left(L_{E}\right)$ (Lobb et al., 1999):

$$
E_{t} \approx f\left(T_{E}, L_{E}\right)
$$

where $E_{t}$ is the tillage erosion rate, resulting from a specific tillage operation. This general concept is illustrated in Figure 6. Tillage erosivity, $T_{E}$, the otential for a given tillage event to erode soil within a landscape, is a function of several physical and human parameters. These include implement characteristics $\left(I_{m}\right)$, (eg, tool shape, width, length), operational parameters $\left(I_{\bullet}\right)$ (eg, tillage depth, speed, tillage direction), the responsiveness of the tillage operator to changing landscape and soil conditions $\left(I_{r}\right)$ (eg, manual depth adjustment to compensate for ower requirement shortage).

$$
E_{T} \approx f\left(I_{m}, I_{o}, I_{r}\right)
$$

Landscape erodibility $L_{E}$ is the propensity of a landscape to be eroded by tillage, and is determined by topographical parameters $\left(I_{t}\right)$ (eg, slope gradient, curvature); field parameters $\left(I_{f}\right)$ (eg, field size and shape) and physical properties of the soil $\left(I_{s}\right)(\mathrm{eg}$, soil texture, soil moisture content, the soil's resistance to displacement by tillage):

$$
E_{L} \approx f\left(I_{t}, I_{f}, I_{s}\right)
$$




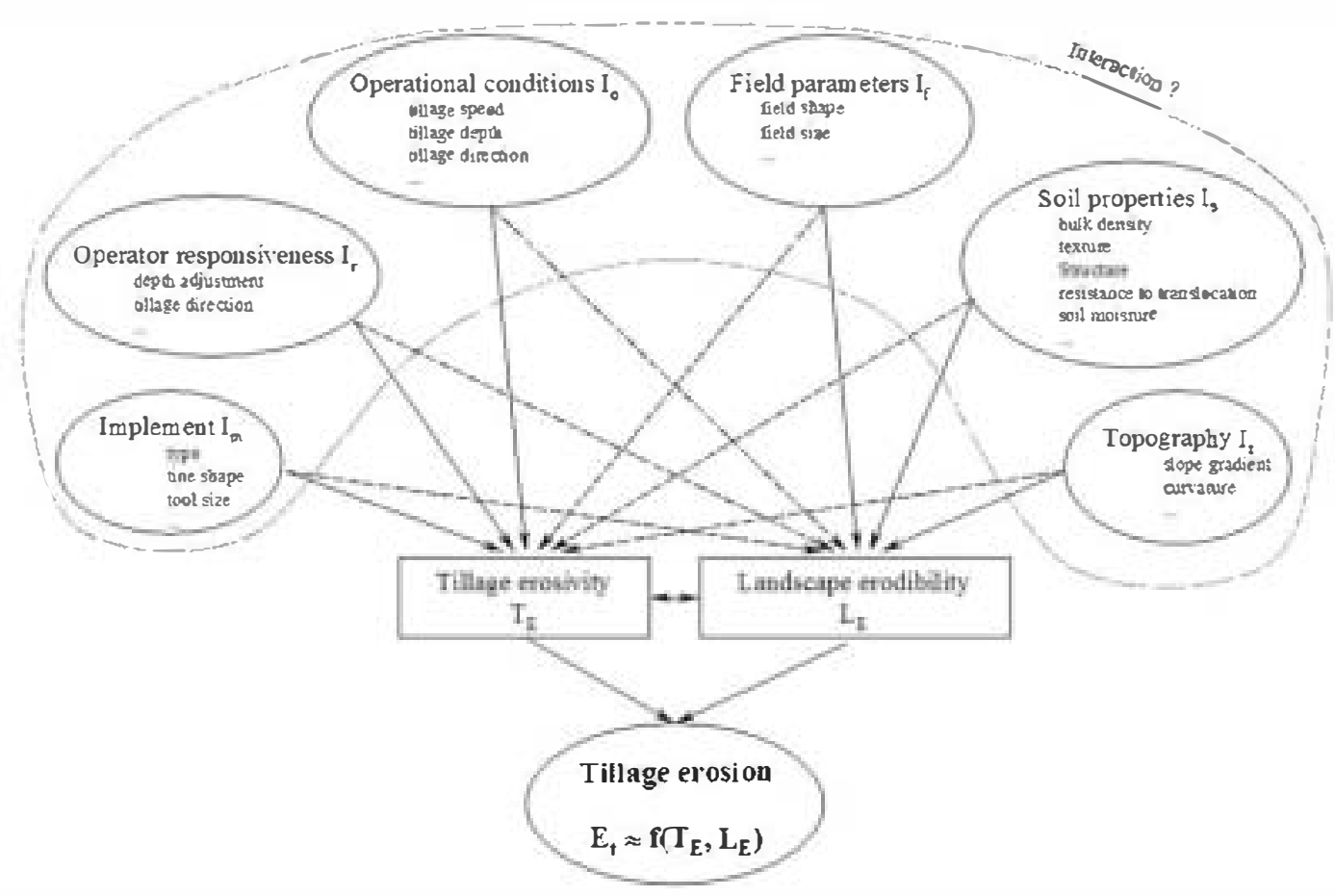

Figure 6 Factors $\bullet$ f tillage eresiøn

It is evident that these fact rs interact. F example, each tillage implement has a recommended depth and speed of operation. Deviations fr mthese values may $\bullet c c u r$, both in response to changing power requirement and availability, as well as to spatial variations in soil roperties, especially in complext pograpy. This will not only affect the implement performance, but it may als influence tillage transløcation and, consequently tillage er sinn. Similarly, the tillage direction applied is decided upon by the farrner, based on information on field size and shape in combination with topographical characteristics.

As landscape erodibility is a static variable

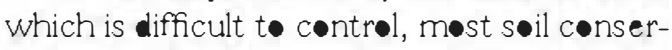
vationstudies focus on the variables reducing tillage erosivity. In the following section, experimental derive tillage transport coefficients reported in literature will be used t• assess tillage erosivity in terms of implement

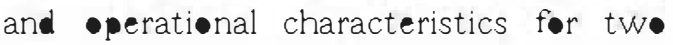

categories of tillage implernents, ie, mouldboard and chisel/cultivator. In addition, the tillage er sivity of sec ndary tillage $\bullet$ perations

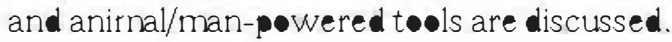

\section{Mouldboand tillage}

Mouldboard tillage is the standard primary tillage technique in many agricultural systems and is therefore the rnost studied implernent in tillage erosion experiments. Mouldboard tillage is essentially a tw-dimensinal process characterized by a displacernent component in the tillage and one perpendicular t tillage direction (turning direction) Tw types of mouldboard tillage experiments can be identified: (i) experiments conducted parallel the steepest gradient (u-and downslope tillage, UD) where only the translocation in the tillage direction is considered and (ii) experiments aløng the contour (cont ur tillage, C) where only translocation in the turning direction is considered. 
Table 1 Comparison of tillage transport coefficient $\left(k_{t i l}\right)$, available in or calculated from the literature for mouldboard tillage

\begin{tabular}{|c|c|c|c|c|c|c|}
\hline Source & Country & $\begin{array}{c}\text { Tillage } \\
\text { speed } \\
\text { V }\left(\mathrm{kmh}^{-1}\right)\end{array}$ & $\begin{array}{l}\text { Tillage } \\
\text { depth } \\
\text { ( }(\mathrm{m})\end{array}$ & $\begin{array}{c}\text { Bulk } \\
\text { density } \\
\text { p. }\left(\mathrm{kg} \mathrm{m}^{-3}\right)\end{array}$ & $\begin{array}{c}k_{t i l} \\
\left(\mathrm{kgm}^{-1} \text { per }\right. \\
\text { operation) }\end{array}$ & $\begin{array}{c}\text { Tillage } \\
\text { direction* }\end{array}$ \\
\hline Lindstrom et al., 1992 & USA & 7.6 & 0.24 & 1350 & 363 & C \\
\hline Van Muysen et al., 2002 & Belgium & 4.9 & 0.26 & 1540 & 184 & C \\
\hline St Gerontidis et al., 2001 & Greece & 4.5 & 0.2 & 142 & 134 & C \\
\hline St Gerontidis et al., 2001 & Greece & 4.5 & 0.3 & 142 & 252 & $\mathrm{C}$ \\
\hline St Gerontidis et al., 2001 & Greece & 4.5 & 0.4 & 1420 & 360 & C \\
\hline de Alba, 2001 & Spain & 4.5 & 0.24 & 1370 & 164 & C \\
\hline Heckrath et al., 2006 & Denmark & 4.9 & 0.23 & 1529 & 49 & C \\
\hline Heckrath et al., 2006 & Denmark & 4.0 & 0.26 & 1490 & 132 & $\mathrm{C}$ \\
\hline Petersen, 1960 & USA & 3.6 & 0.16 & 1239 & 64 & C \\
\hline Montgomery et al., 1999 & USA & 3.6 & 0.23 & 1310 & 109 & C \\
\hline Heckrath et al., 2006 & Denmark & 4.9 & 0.24 & 1555 & 281 & $\mathrm{~S}$ \\
\hline Heckrath et al., 2006 & Denmark & 4.1 & 0.24 & 1449 & 239 & S \\
\hline Heckrath et al., 2006 & Denmark & 4.1 & 0.22 & 1423 & 137 & S \\
\hline Quine et al., 2003 & New Zealand & 7.0 & 0.17 & 1350 & 324 & UD \\
\hline Lindstrom et al., 1992 & USA & 7.6 & 0.24 & 1350 & 330 & UD \\
\hline Govers et al., 1994 & Belgium & 4.5 & 0.28 & 1350 & 234 & UD \\
\hline Van Muysen et al., 1999 & Spain & 1.8 & 0.33 & 1070 & 245 & UD \\
\hline Van Muysen et al., 1999 & Spain & 2.7 & 0.15 & 1650 & 85 & UD \\
\hline Van Muysen et al., 2002 & Belgium & 5 & 0.25 & 1500 & 224 & UD \\
\hline Van Muysen et al., 2002 & Belgium & 5.4 & $\mathbf{0 . 2 1}$ & 1560 & 169 & UD \\
\hline Lobbet al., 1995 & Canada & 4 & 0.15 & 1350 & 184 & UD \\
\hline Lobb et al., 1999 & Canada & 6.2 & 0.23 & 1350 & 346 & UD \\
\hline Revel and Guiresse, 1995 & France & 6.5 & 0.27 & 1350 & 263 & UD \\
\hline Mech and Free, 1942 & USA & 3.6 & 0.08 & 1155 & 24 & UD \\
\hline St Gerontidis et al., 2001 & Greece & 4.5 & 0.2 & 142 & 153 & UD \\
\hline St Gerontidis et al., 2001 & Greece & 4.5 & 0.3 & 142 & 383 & UD \\
\hline St Gerontidis et al., 2001 & Greece & 4.5 & 0.4 & 1420 & 670 & UD \\
\hline de Alba, 2001 & Spain & 4.5 & 0.24 & 1370 & 204 & UD \\
\hline Heckrath et al., 2006 & Denmark & 4.9 & 0.25 & 1517 & 200 & UD \\
\hline Heckrath et al., 2006 & Denmark & 6.3 & 0.26 & 1507 & 335 & UD \\
\hline da Silva et al., 2004 & Portugal & 3.7 & 0.39 & 1680 & 770 & UD \\
\hline Quine and Zhang, 2004b & UK & 5.9 & 0.21 & 1374 & 101 & UD \\
\hline Kosmas et al., 2001 & Greece & 4.5 & 0.18 & 1598 & 63 & UD \\
\hline Kosmas et al., 2001 & Greece & 4.5 & 0.25 & 1598 & 159.8 & UD \\
\hline
\end{tabular}

* Tillage direction: contour (C), slantwise (S), up and doinn (UD)

In Table 1, the results of 34 mouldboard tillage experiments are listed with their operational characteristics and tillage transport coefficient. 24 experiments were performed under up- and downslope (or slantwise) tillage while 10 are contour tillage experiments. The experiments exhibit a wide range in tillage speed (range 1.4-7.6km h-1) and tillage depth (range 0.08-0.4 m). Although these studies report only average values for the tillage speed and depth applied during the experiment, they provide a valuable basis for assessing the operational effects on mouldboard tillage erosivity. We use a non-linear regression of the form:

$$
k_{t i l}=\boldsymbol{a} \rho_{\mathbf{b}} \boldsymbol{D}^{a} V^{\boldsymbol{\beta}}
$$


A similar approach has previously been used by (Van Muysen et al., 2002) Equation (9) is capable of predicting the trends observed in the published data $\left(r^{2}=\mathbf{0 . 6 7} ; \mathrm{P}<\mathbf{0 . 0 0 0 1}\right)$
(Figure $7 \mathrm{a}$ and Table 5) The regression analysis indicates that tillage erosivity largely depends on tillage depth while the effect of tillage speed is less prounced. However,

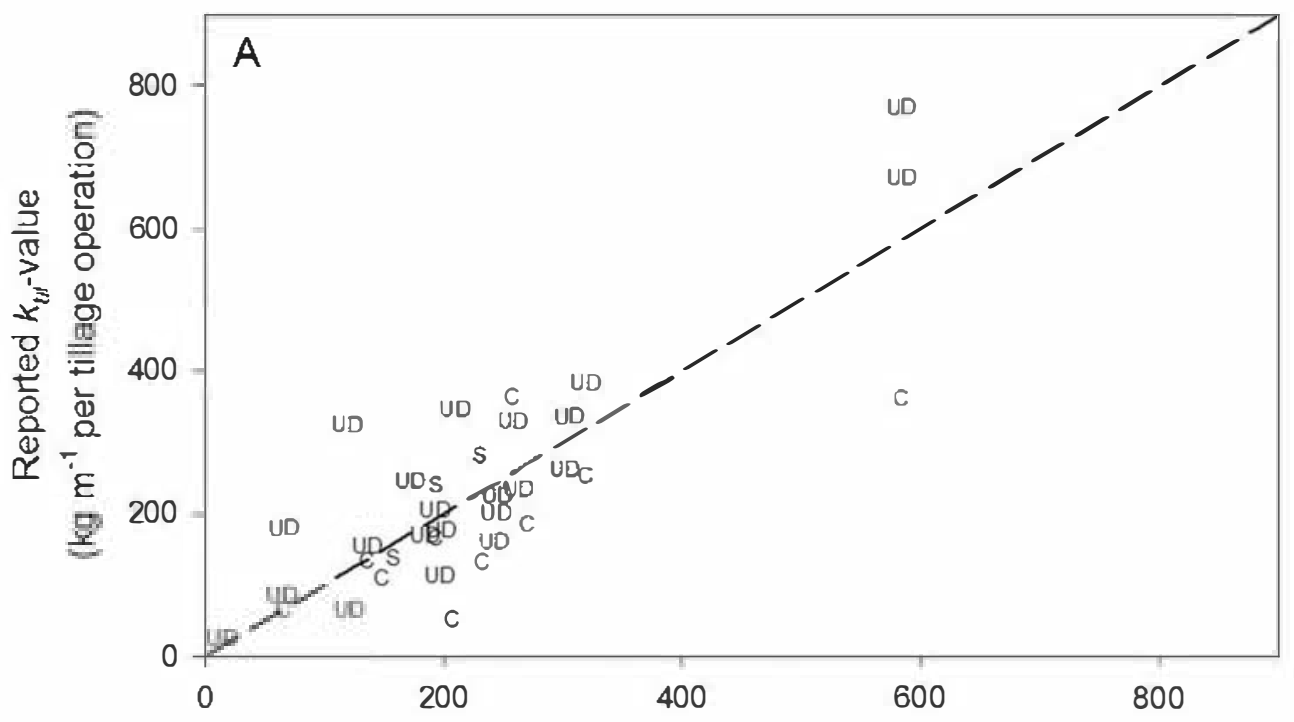

Predicted $k_{t i t}$-value $\left(\mathrm{kg} \mathrm{m}^{-1}\right.$ per tiliage operation)

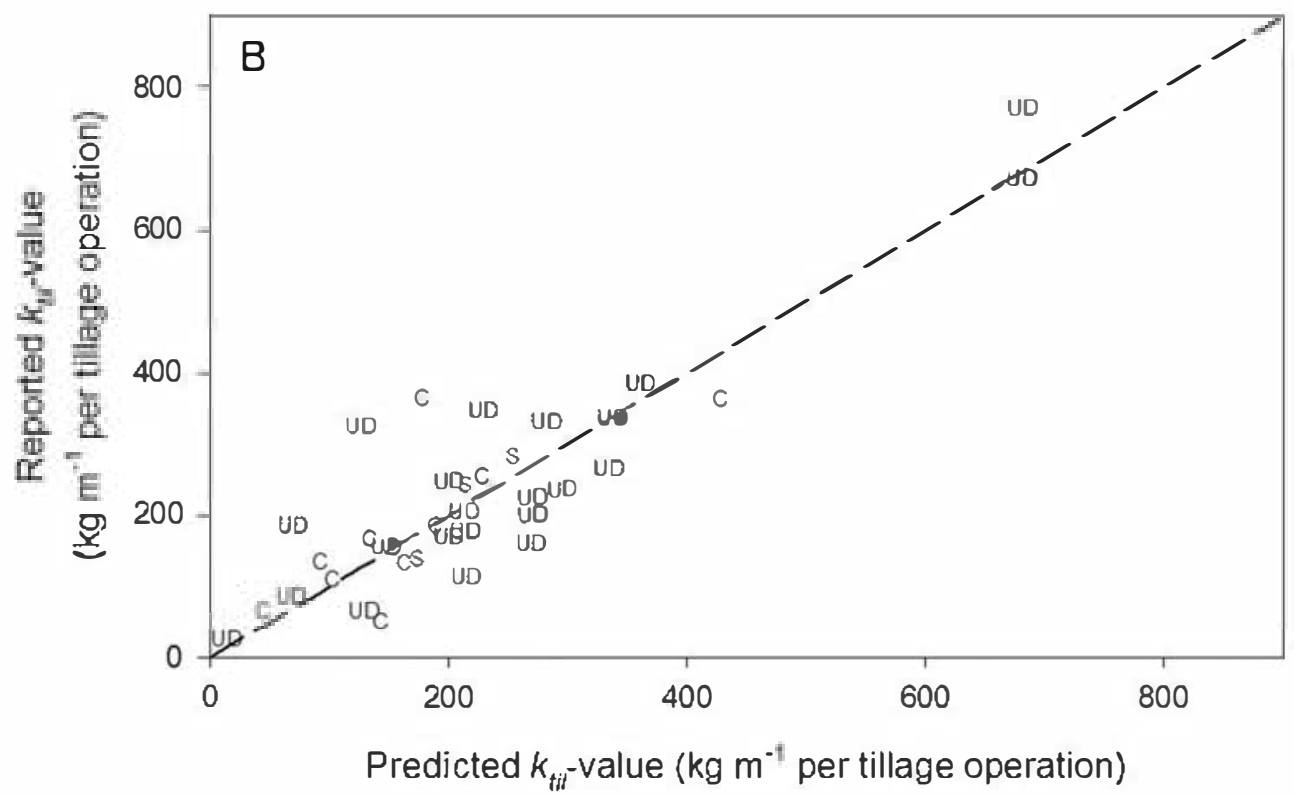

Figure 7 Relationship between predicted tillage transport coefficient and reported $k_{\text {til }}$ values for data sets on mouldboard tillage for up-and downslope tillage (UD) and contour tillage (C) using (A) equation 9 and (B) equation 10 
the inclusion of a dummy variable to account for the direction of tillage, that is:

$$
k_{t i l}=\boldsymbol{a} p_{\mathbf{b}} \boldsymbol{D}^{\alpha} V^{\beta} T^{\gamma}
$$

where T equals I for contour tillage and 2 for upand downslope tillage, considerably improved the regression $\left(\mathrm{r}^{2}=\mathbf{0 . 7 9} ; \mathrm{P}<\mathbf{0 . 0 0 0 1}\right)$ (Figure 7b and Table 5).

Figure 8 shows the tillage transport coefficients for u- and downslope and contour tillage for different values of tillage speed and depth based on this statistical model. Tillage depth is the most important factor. For example, the $k_{t i l, U}$-value increases with $141 \%$ if tillage depth changes from 0.2 to $0.3 \mathrm{~m}$ $\left(\mathrm{V}=4 \mathrm{kmh}^{-1}\right)$. This effect corroborates findings by Van Muysen et al. (2002), St Gerontidis et al. (200l) and Heckrath et al. (2006), reporting values for between $\mathrm{I}$ and 2 . The effect of tillage depth on mouldboard erosivity can be explaine as follows: tillage erosion rates, and consequently tillage erosivity, increase linearly with tillage depth as more soil is subject to transport (see equation 5). The additional increase in mouldboard erosivity is related to the larger volume soil occupies after ploughing. Gravitational forces amplify the spreading of this larger volume of soil during downslope tillage while the spreading is hampered during upslope tillage. Tillage speed also increases mouldboard erosivity but to a lesser extent. For example, the $k_{t i l, U}$-value increases with only $20 \%$ if tillage speed

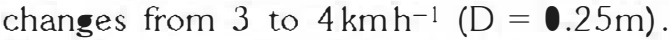
Van Muysen et $\mathbf{a l}$. (2002) and Heckrath et al. (2006) reported values between 0.39 and 0.96 for $\boldsymbol{\beta}$, which is comparable to the value of $\mathbf{0 . 6}$ derived here.

This analysis shows that tillage direction has an important control on mouldboard erosivity. The value of $\mathbf{0 . 7 1}$ for $\gamma$ means that the ratio between $k_{t i l}$-values for up- and downslope $\left(k_{t i l, U}\right)$ tillage and contour tillage $\left(k_{t i l, C}\right)$ is 1.64 , or that up- and downslope mouldboard tillage is more erosive than contour tillage. Experimental studies where contour and upand downslope tillage were directly compared report similar ratios of 1.22 (Van Muysen et al., 2002), 1.14-1.86 (St Gerontidis et al., 2001) and 1.24 (De Alba, 2001). In contrast, Lindstrom et al. (1992) found that contour tillage was slightly more erosive than up-and downslope tillage (ratio 0.91 ).

The differential behaviour in soil translocation dynamics for contour and up- and downslope tillage strongly suggests that a l-dimensional analysis of soil translocation, where slope gradient only varies in a single direction, is not applicable in real 2dimensional landscapes. Moulboard tillage is characterize by a dis lacement component in the tillage and turning direction and each of these can be affected by the slope in the tillage and turning direction. De Alba (2001), Quine and Zhang (2004a) and Heckrath et $\boldsymbol{a l}$. (2006) showed that the simultaneous change of slope gradients in both tillage and turning direction may exert an import influence on mouldboard erosivity. These are important findings as under normal agricultural practice on hummocky terrain simultaneously changing slope gradients in tillage and turning direction will be rather common as field geometry, more than topography, determines the tillage direction. Heckrath et al. (2006) presented the first study where the effect of simultaneously changing slope gradients in tillage and turning direction were investigated. They concluded that contour tillage was the least erosive, followed by slantwise tillage turning the soil upslope $\left(k_{t i l}=110 \mathrm{~kg} \mathrm{~m}^{-1}\right)$ while upand downslope tillage was considered to be the most erosive $\left(k_{t i l}=180-210 \mathrm{~kg} \mathrm{~m}^{-1}\right)$.

\section{Chisel tillage}

In contrast with mouldboard tillage, relatively few tillage erosion studies report on chisel experiments and the variables controlling chisel erosivity are scarcely studied. In Table 2, all available experimental data is summarized. Although the typical working depth of a chisel operation is smaller than mouldboard operations, $k_{t i l}$ values reported are only slightly lower than those for mouldboard tillage. The observed $k_{t i l}$ values could be described by a model regression similar to 

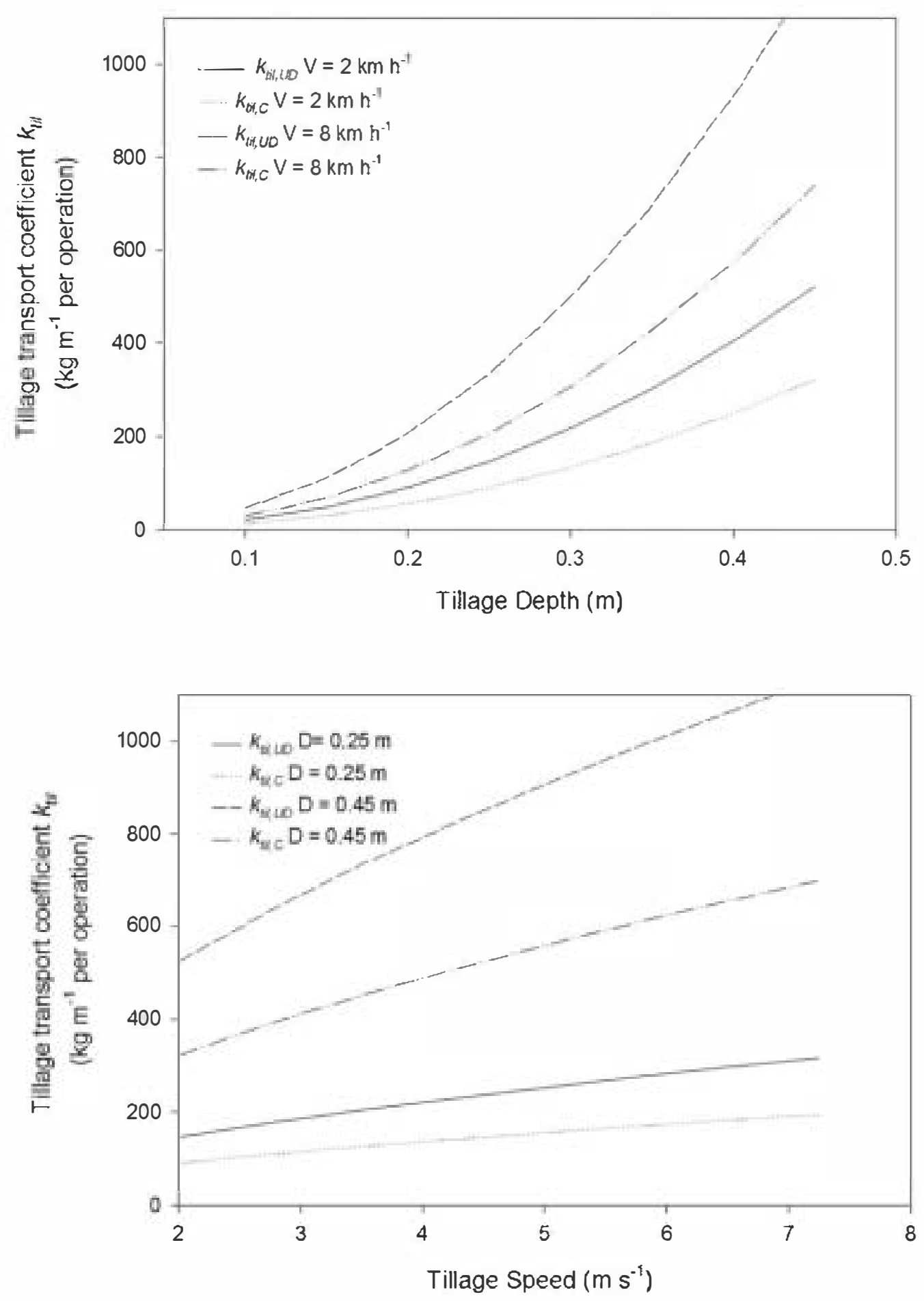

Figure 8 Mouldbeard erøsivity of up-and downslope $\left(k_{t i}, u_{\boldsymbol{b}}\right)$ and cøntour tillage $\left(k_{t i l, C}\right)$ for different tillage speed and depth combinations 
Table 2 Comparison of tillage transport coefficient $\left(k_{t i l}\right)$, available in or calculated from the literature for chisel tillage

\begin{tabular}{|c|c|c|c|c|c|}
\hline Source & Country & $\begin{array}{l}\text { Tillage speed } \\
\vee\left(\mathrm{kmh}^{-1}\right)\end{array}$ & $\begin{array}{c}\text { Tillage } \\
\text { depth } \mathbf{D}(\mathrm{m})\end{array}$ & $\begin{array}{l}\text { Bulk density } \\
\text { م. }\left(\mathrm{kg} \mathrm{m}^{-3}\right)\end{array}$ & $\begin{array}{c}k_{t i l}\left(\mathrm{~kg} \mathrm{~m}^{-1}\right. \\
\text { per operation) }\end{array}$ \\
\hline Van Muysen et al., 2000 & Belgium & 5.8 & 0.15 & 1560 & 225 \\
\hline Van Muysen et al., 2000 & Belgium & 7.2 & 0.2 & 1250 & 545 \\
\hline Poesen et al., 1997 & Spain & 2.3 & 0.16 & 1582 & 282 \\
\hline Poesen et al., 1997 & Spain & 2.3 & 0.14 & 1582 & 139 \\
\hline Govers et al., 1994 & Belgium & 4.5 & 0.15 & 1350 & 111 \\
\hline Lobb et al., 1999 & Canada & 9.6 & 0.17 & 1580 & 275 \\
\hline Mech and Free, 1942 & USA & 3.6 & 0.06 & 1155 & 13 \\
\hline Quine et al., 1999a & Spain & 2.2 & 0.19 & 1371 & 657 \\
\hline da Silva et al., 2004 & Portugal & 3.6 & 0.11 & 1600 & 75 \\
\hline da Silva et al., 2004 & Portugal & 3.4 & 0.19 & 1600 & 27 \\
\hline
\end{tabular}

equation (9) (Table 3, $\mathrm{r}^{2}=\mathbf{0 . 8 9}, \mathbf{p}=\mathbf{0 . 0 0 5}$ ). Tillage depth strongly affects tillage erosivity while the effect of tillage speed was not significant. This sharply contrasts with the findings of Van Muysen et al. (2000). Using the results of a chisel experiment where speed and depth were varied, they suggested that chisel erosivity increases almost linearly with tillage speed and depth. However, it is evident that the model parameters derived here are based on a rather limite data set covering a wide range of soil conditions and chisel implements. It is likely that most of the observed variability is related to implement characteristics. Studies reporting high chisel $k_{t i l}$ values (Poesen et al., 1997; Quine et al., 1999a) were conducted with a duckfoot chisel at very low speeds. Van Muysen et al. (2000) suggested that the wide tines used on a duckfoot chisel were responsible for the high translocation rates observed by Poesen et al. (1997) and Quine et al. (1999a). Typically, the implement coverage for a duckfoot chisel is c. 3 times higher than a chisel plough. It is clear that further experimental research is needed to assess the factors controlling chisel erosivity.

Table 3 Summary of results from regression analysis for mouldboard, chisel and nonmechanized tillage implements

\begin{tabular}{|c|c|c|c|c|c|}
\hline & $\mathrm{a}$ & $\propto$ & $\beta$ & $\gamma$ & $r^{2}$ \\
\hline \multicolumn{6}{|l|}{ Mouldboard } \\
\hline $\begin{array}{c}k_{t i l}=a_{p} D \cdot V \cdot \\
(n=34)\end{array}$ & $\begin{array}{l}1.17 \\
\quad(p=0.027)\end{array}$ & $\begin{array}{l}2.10 \\
\quad(p<0.00 I)\end{array}$ & $\begin{array}{l}0.58 \\
\quad(p=0.065)\end{array}$ & - & $\begin{array}{l}0.67 \\
\quad(p<0.00 I)\end{array}$ \\
\hline $\begin{array}{c}k_{t i l}=a_{p,} D \cdot V \cdot T \gamma \\
(\mathrm{n}=34)\end{array}$ & $\begin{array}{l}0.97 \\
\quad(p=0.008)\end{array}$ & $\begin{array}{l}2.21 \\
\quad(p<0.00 I)\end{array}$ & $\begin{array}{l}0.57 \\
(p=0.027)\end{array}$ & $\begin{array}{l}0.67 \\
(p=0.0015)\end{array}$ & $\begin{array}{l}0.78 \\
\quad(p<0.00 I)\end{array}$ \\
\hline \multicolumn{6}{|l|}{ Chisel } \\
\hline$k_{t i l}=a p_{b} D a(n=6)$ & $\begin{array}{l}1157 \\
\quad(p=0.52)\end{array}$ & $\begin{array}{l}4.84 \\
\quad(p=0.005)\end{array}$ & - & - & $\begin{array}{l}0.89 \\
\quad(p=0.005)\end{array}$ \\
\hline \multicolumn{6}{|l|}{ Non-mechanized } \\
\hline$k_{t i l}=a_{p, b} D a(n=7)$ & $\begin{array}{l}0.358 \\
\quad(p=0.06)\end{array}$ & $\begin{array}{l}0.71 \\
\quad(p=0.03)\end{array}$ & - & - & $\begin{array}{l}0.68 \\
\quad(p=0.02)\end{array}$ \\
\hline
\end{tabular}

plentes statistical significance 


\section{Secondary tillage operations}

Although mouldboard and chisel plough tillage make up the major part of an annual sequence of tillage operations under mechanized agriculture, they do generally not result in a surface that is smooth enough for seeding or planting. In many cases, mouldboard and chisel tillage is followed by harrowing or discing to reduce clod size and surface smoothening before seeding is carried out. In Table $4, k_{t i l}$ values for harrow, cultivator and disc implements are shown. Tillage erosivity for harrow and cultivator tillage is significantly lower than mouldboard and chisel tillage. In contrast, da Silva et al. (2004) and Lobb et (1999) report very high values for disc implements. da Silva et al. (2004) found that tillage depth, and to a lesser extent tillage speed and disc characteristics, had a major influence on disc erosivity.

\section{Animal-and man-powered tillage tools}

Only recently studies addressed tillage erosion by animal and man-powered tillage tools, which are common in present-day farming systems in developing countries. Lewis and Nyamulinda (1996), Turkelboom et al. (1997) and Zhang et al. (2004a; 2004b) demonstrated that manual tillage on steep slopes leads to significant downslope movement of soil. Rymshaw et al. (1997), Thapa et al. (1999a; 1999b), Quine et al. (1999b) and
Nyssen et (2000) pointed out that shallow mouldboard or ard ploughing using animal traction can be very erosive. Table 5 summarizes all available tillage transport coefficients for animal- and man-powered tillage tools. The tillage transport coefficients are much lower than those associated with mechanized tillage operations and range between 30 and $250 \mathrm{~kg} \mathrm{~m}^{-1}$ per operation (compare with Table l). This must be attributed to the typically lower tillage speeds and working depths associated with man- and animal-powere tillage tools as well as substantially different implement characteristics. Thapa et al. (1999a) compared up- and downslope tillage and contour tillage with an animal-powered mouldboard. They concluded that up- and downslope tillage with an animal-powered tool was 1.27 times more erosive than contour tillage, which is in the same order of magnitude as the ratios oserved for mechanized mouldboard tillage.

\section{Crop rot ation tillage transport coefficients}

In most agricultural systems, multiple tillage operations with different implements are require for cro cultivation. It is therefore useful not to express tillage erosivity on an implement basis, but to consider the erosivity of a typical sequence of tillage operations associate with a specific croping system.

Table 4 Comparison of tillage transport coefficient $\left(k_{t i l}\right)$, available in or calculated from the literature for secondary tillage operations

\begin{tabular}{|c|c|c|c|c|c|c|}
\hline Source & Country & $\begin{array}{c}\text { Tillage } \\
\text { speed } \\
\mathrm{V}\left(\mathrm{kmh}^{-1}\right)\end{array}$ & $\begin{array}{l}\text { Tillage } \\
\text { depth } \\
\text { D (m) }\end{array}$ & $\begin{array}{c}\text { Bulk } \\
\text { density } \boldsymbol{p}_{\mathbf{b}} \\
\left(\mathrm{kg} \mathrm{m}^{-3}\right)\end{array}$ & $\begin{array}{c}\quad k_{t i l} \\
\left(\mathrm{~kg} \mathrm{~m}^{-1} \text { per }\right. \\
\text { operation) }\end{array}$ & Implement \\
\hline Lobb et al., 1999 & Canada & 6.9 & 0.15 & 1580 & 13 & cultivator \\
\hline Mech and Free, 1942 & USA & n.a. & 0.08 & n.a. & 28 & cultivator \\
\hline Mech and Free, 1942 & USA & n.a. & 0.12 & n.a. & 78 & harrow \\
\hline $\begin{array}{l}\text { Van Muysen and } \\
\text { Govers, } 2002\end{array}$ & Belgium & 6.8 & 0.07 & 1130 & 123 & $\begin{array}{c}\text { rotary harrow } \\
\text { and seeder }\end{array}$ \\
\hline da Silva et al., 2004 & Portugal & 5.3 & 0.07 & 1650 & $9-333$ & harrow disc \\
\hline da Silva et al., 2004 & Portugal & 2.9 & 0.08 & 1178 & $18-770$ & harrow disc \\
\hline Lobbet al., 1999 & Canada & 3.0 & 0.17 & 1580 & 369 & tandem disc \\
\hline
\end{tabular}

n.a.: data n available 
Table 5 : Comparison of tillage transport coefficient $\left(k_{t i l}\right)$, available in or calculated from the literature for non-mechanized agriculture

\begin{tabular}{|c|c|c|c|c|c|c|}
\hline Source & Country & $\begin{array}{c}\text { Tillage } \\
\text { speed } \\
\mathrm{V}\left(\mathrm{kmh}^{-1}\right)\end{array}$ & $\begin{array}{l}\text { Tillage } \\
\text { depth } \\
\text { D (m) }\end{array}$ & $\begin{array}{c}\text { Bulk } \\
\text { density } \\
\text { p. }\left(\mathrm{kg} \mathrm{m}^{-3}\right)\end{array}$ & $\begin{array}{c}\quad k_{t i l} \\
\left(\mathrm{~kg} \mathrm{~m}^{-1} \text { per }\right. \\
\text { operation) }\end{array}$ & $\begin{array}{c}\text { Tillage } \\
\text { direction* }\end{array}$ \\
\hline Nyssen et al., 2000 & Ethiopia & 1.1 & 0.08 & 1143 & $68^{a}$ & C \\
\hline Thapa et al., 1999a & Philippines & n.a. & 0.2 & 730 & $76^{a}$ & C \\
\hline Quine et al., 1999c & China & n.a. & 0.17 & 1300 & 31 & $\mathrm{C}$ \\
\hline Thapa et al., 1999b & Philippines & n.a. & 0.2 & 1000 & $119^{a}$ & $\mathrm{C}$ \\
\hline $\begin{array}{l}\text { Dercon et al., unpublished } \\
\text { data }\end{array}$ & Ecuador & n.a. & 0.13 & 1203 & $83^{a}$ & $\mathrm{C}$ \\
\hline Rymshaw et al., 1997 & Venezuela & n.a. & 0.2 & 1270 & $29 a$ & C \\
\hline Thapa et al., 1999b & Philippines & n.a. & 0.2 & 1000 & $152^{\mathrm{a}}$ & UD \\
\hline Quine et al., 1999c & China & n.a. & 0.17 & 1300 & 250 & UD \\
\hline Turkelboom et al., 1999 & Thailand & n.a. & 0.085 & 1100 & $77 \mathrm{~m}$ & UD \\
\hline Zhang et al., 2004b & China & n.a. & 0.22 & 1310 & $14 \mathrm{l}^{\mathrm{m}}$ & UD \\
\hline Kimaro et al., 2005 & Tanzania & n.a. & 0.05 & 1200 & $84-108 m$ & UD \\
\hline
\end{tabular}

animal-powered tillage; $m$ manual tillage

Tillage direction: contur (C), slantwise (S), up and deivn (UD)

n.a.: data not available

Lobb et al. (1995) reported on the results of a series of tillage erosion experiments in Canada whereby the erosivity of a sequence of conventional tillage operations (I mouldboard pass, 2 tandem disc passes and 1 tine cultivator pass) was studied. The tillage transport coefficient for this sequence was estimated as $473-734 \mathrm{~kg} \mathrm{~m}^{-1}$. Van Muysen et al. (2006) studied a typical tillage sequence for mechanized agriculture, including multiple mouldboard, chisel and harrow passes, during a perio of three years. These authors derived a tillage transport coefficient of $781 \mathrm{~kg} \mathrm{~m}^{-1} \mathrm{yr}^{-1}$, which is in good agreement with data reported in literature. This study also showed that the tillage transport coefficient of a sequence of tillage operations can be reasonably well predicted by summing the transport coefficients obtained from controlled, single pass experiments.

Crop rotation tillage trans ort coefficients can also be derived from ${ }^{137} \mathrm{C}$ s data. This technique uses present-day ${ }^{137} \mathrm{C}$ s inventories to otimize the arameters of satially distributed soil erosion-deposition models that take into account all relevant processes (ie, water erosion, tillage erosion, and soil loss due to crop harvesting), so that the observed ${ }^{137} \mathrm{Cs}$ redistribution pattern is predicted as accurately as possible (Govers et al., 1996; Quine et al., 1997; Quine, 1999; Schuller et al., 2003; Van Oost et al., 2003a; Schoorl et al., 2004). Table 6 presents the $k_{t i l}$ values derived from ${ }^{137} \mathrm{Cs}$ data. The clearest characteristic of the data is the high degree of similarity in the $k_{t i l}$ values for mechanized agriculture, ranging

Table 6 Long-term tillage transport coefficients inferred from ${ }^{137} \mathrm{C}$ s data

\begin{tabular}{lcc}
\hline Source & Country $\begin{array}{c}k_{\text {til }} \text { value } \\
\left(\mathrm{kg} \mathrm{m}^{-1} \mathrm{yr}^{-1}\right)\end{array}$ \\
\hline
\end{tabular}

Mechanized agriculture

$\begin{array}{lll}\text { Govers et al., 1996 } & \text { UK } & 397 \\ \text { Govers et al., 1996 } & \text { UK } & 348 \\ \text { Van Oost et al., 2003a } & \text { Belgium } & 523 \\ \text { Quine et al., 1996 } & \text { UK } & 300 \\ \text { Quine et al., 1994 } & \text { Belgium } & 550 \\ \text { Heckrath et al., 2005 } & \text { Denmark } & 456\end{array}$

Non-mechanized agriculture

\begin{tabular}{llc} 
Quine et al., 1999b & China & 108 \\
Quine et al., 1999b & Lesotho & 243 \\
Quine et al., 1999b & Zimbabwe & 113 \\
Quine et al., 1997 & China & $20-40$ \\
\hline
\end{tabular}


between 350 and $550 \mathrm{~kg} \mathrm{~m}^{-1}$ year ${ }^{-1}$. It is important to note that the $k_{t i l}$ values derived from this technique represent average tillage erosion intensities over the last 35-45 years (depending on the sampling date) and are therefore lower than present-day $k_{t i l}$ values, based on tillage erosion experiments, due to the increase of mechanical power during the last decades.

Although the erosivity of individual tillage operations use in non-mechanized agriculture is substantially lower than those used in mechanized agriculture (Table 6), crop rotation tillage trans ort coefficients reported are relatively high. Dercon et al. (unpublished data) obtained $k_{t i l}$ values between 168 and $681 \mathrm{~kg} \mathrm{~m}^{-1}$ year $^{-1}$ for a typical cropping cycle in the Andes. Nyssen et al. (2000) report an annual $k_{t i l}$ value between 68 and $272 \mathrm{~kg} \mathrm{~m}^{-1}$ year $^{-1}$ for agriculture in the Ethiopian highlands while Thapa et al. (1999a; 1999b) otaine $k_{t i l}$ values between 260 and $710 \mathrm{~kg} \mathrm{~m}^{-1}$ year $^{-1}$ for various tillage systems in intensive cropping systems in the humid tropics.

\section{Rates of tillage erosion}

While tillage transport coefficients allow comparison of potential tillage erosion intensity between tillage implements and management options, actual rates of tillage erosion are dependent on the interaction of tillage translocation with topography. In Table 7, we present tillage erosion rates reporte in literature, based on direct measurement, ${ }^{137} \mathrm{Cs}$ data or derived from modelling studies. Erosion rates reported range between 3 and $70 \mathrm{Mgha}^{-1} \mathrm{yr}^{-1}$ for mechanized agriculture. Despite the fact that tillage erosivity is generally higher for mechanized agriculture, erosion rates reported for non-mechanized agriculture are also high and range between 3 and $600 \mathrm{Mgha}^{-1} \mathrm{yr}^{-1}$. The high values for nonmechanized agriculture must be attributed to the fact that most studies report rates on stee slopes in intensive cropping systems.

The significance of the tillage erosion process in the total soil redistribution on arable land can be derived from Table 7.
Here, we report the relative contribution of tillage in the total soil redistribution on arable land for Europe, North and South America, Africa, Asia and Oceania. Two features are noteworthy. First, the data clearly indicates that, under mechanized agriculture, tillage erosion rates are at least in the same order of magnitude or higher than water erosion rates, in almost all cases. Second, tillage erosion also contributes substantially to the total soil redistribution under non-mechanized agriculture. These estimates of the relative importance of tillage and water erosion are consistent with the Canadian AgriEnvironmental Indicator Project (McRae et al., 2000), which is at present the only attempt to assess the significance of tillage erosion at the regional scale. It was concluded that approximately $50 \%$ of the cropland in Canada was subject to unsustainable levels of tillage erosion ( $>6 \mathrm{Mgha}^{-1} \mathrm{yr}^{-1}$ ) while only approximately $15 \%$ of the cropland was subject to unsustainable levels of water erosion. Equivalent data are not available for other regions. Direct estimation of tillage erosion rates for large areas is not always possible as detailed information about topographic curvature would be required, which cannot be reliably deduced from the large-scale DEMs which are presently available. In contrast to slope gradient (first terrain derivative), slope curvature (second terrain derivative) cannot be represented realistically, and is significantly underestimated, when derived from a coarse DEM (ie, $+20 \mathrm{~m}$ resolution).

\section{Consequences for soil quality}

Close relationships between the spatial distribution of tillage erosion and the spatial patterns of total C, N, P, texture, soil depth, rock fragment cover and above ground biomass have been reported (Van Oost et al., 2000 b; Kosmas et al., 2001; Quine and Zhang, 2002; Li et al., 2004; Heckrath et al., 2005). These results have provided evidence that tillage erosion operates like a conveyor belt, transferring soil and associated constituents from convexities to concavities. During cultivation, 
Table 7 Comparison of tillage and water erosion rates, available in or calculated from the literature

\begin{tabular}{|c|c|c|c|c|}
\hline Authors & Country & $\begin{array}{c}\text { Tillage rate } \\
\left(\mathrm{Mgha}^{-1} \mathrm{yr}^{-1}\right)\end{array}$ & $\begin{array}{c}\text { Water rate } \\
\left(\mathrm{Mgha}^{-1} \mathrm{yr}^{-1}\right)\end{array}$ & Ratio \\
\hline \multicolumn{5}{|l|}{ Mechanized agriculture } \\
\hline St Gerontidis et al., 2001 & Greece & 23 & 1 & 23 \\
\hline Tsara et al., 2001 & Greece & $4.0-18$ & & $>15$ \\
\hline Van Oost et al., 2003a & Belgium & 10 & 2 & 5 \\
\hline Lobb et al., 1995 & Canada & 54 & & 2.3 \\
\hline Poesen et al., 1997 & Spain & $40-60$ & & 10 \\
\hline Kosmas et al., 2001 & Greece & & & $>>1$ \\
\hline Quine et al., 2003 & New Zealand & 19 & & $>>1$ \\
\hline Quine and Zhang, 2002 & UK & & & $>>1$ \\
\hline Quine et al., 1997 & Belgium & & & $>1$ \\
\hline Govers et al., 1996 & UK & & & $>1$ \\
\hline Montgomery et al., 1997 & USA & & & $>1$ \\
\hline Govers et al., 1994 & Belgium & & & 1 \\
\hline Van Oost et al., 2000a & Belgium & 8.7 & 9.2 & 0.9 \\
\hline Schuller et al., 2003 & Chile & & & $0.5-1.2$ \\
\hline Dabney et al., 1999 & USA & 81 & & $0.3-1.5$ \\
\hline Lobb and Kachanoski, 1999 & Canada & & & $0.2-1$ \\
\hline Basher and Ross, 2002 & New Zealand & & & 0.15 \\
\hline \multicolumn{5}{|l|}{ Non-mechanized agriculture } \\
\hline Thapa et al., 1999a & Philippines & $106-601$ & & 2.7 \\
\hline Quine et al., 1999b & Lesotho & 19 & 14 & 1.4 \\
\hline Quine et al., 1999b & Zimbabwe & 2.9 & 2.5 & 1.2 \\
\hline Thapa et al., 2001 & Philippines & & & $>>1$ \\
\hline Rymshaw et al., 1997 & Venezuela & & & $>>1$ \\
\hline Dercon et al., 2003 & Ecuador & & & $>1$ \\
\hline Nyssen et al., 2001 & Ethiopia & & & 1 \\
\hline Nyssen et al., 2000 & Ethiopia & & & 1 \\
\hline Lewis and Nyamulinda, 1996 & Rwanda & 68 & & 1 \\
\hline Li and Lindstrom, 2001 & China & 16.9 & 17.9 & 0.9 \\
\hline Quine et al., 1999c & China & $14-55$ & $10-29$ & $0.5-5.5$ \\
\hline Quine et al., 1999b & China & 18 & 34 & 0.5 \\
\hline Turkelboom et al., 1997 & Thailand & $8-18$ & $25-70$ & 0.3 \\
\hline Li and Lindstrom, 2001 & China & 8.8 & 47.5 & 0.2 \\
\hline Quine et al., 1997 & China & & & $<1$ \\
\hline Zhang et al., 1998 & China & & & $<<1$ \\
\hline
\end{tabular}

a Tillage er sion/water er sion rate rati

there is a net loss of plough soil from convex slope elements. However, the plough layer depth is maintained here by incorporation of nutrient-por subsoil into the plough layer. Consequently, the plough soil on these eroded convexities becomes depleted in surface-applied or surface-immobilized nutrients and the products of weathering. This depleted plough soil is also translocated away from the convexities and, therefore, areas of no (or limited) net soil loss on linear slope elements below convexities may also be characterized by nutrient-depletion of the plough soil. Conversely, plough soil accumulates in 
concavities through downslope translocation from the uslope landscape elements. These areas, therefore, develop overdeepened plough soil enriched in nutrients. Therefore, translocation of soil by tillage erosion is a major contributor to within-field variability in soil properties. Model simulations indicate that continuing tillage will further increase the spatial variability of soil properties (Quine and Zhang, 2002; Van Oost et al., 2003b; de Alba et al., 2004). Other studies provide evidence that tillage erosion has a deleterious impact on crop production (Aase and Pikul, 1995; Schumacher et al., 1999; Kosmas et al., 2001; Tsara et al. , 2001). More recently, Bakker et al. (2005) report on the effect of erosion-induce reductions in crop productivity on land-use change and concluded that the spatial pattern on land use is significantly affected by crop yield-erosion relationships. Tillage induce spatial variation in soil properties and cro yields is, however, not limited to mechanized agriculture. The importance of tillage in redistributing soil and soil constituents has also been recognized for non-mechanized agriculture, especially on terraced fields (Li and Lindstrom, 2001; Thapa et al., 2001; Dercon et al., 2003).

\section{Discussion and conclusion}

Although the tillage erosion experiments reported in literature were conducted in a variety of agricultural environments in terms of soil type, surface conditions and implement characteristics, the $k_{t i l}$ values for different tillage implements are very consistent: the data available strongly suggests that tillage depth is the most important factor affecting tillage erosivity. Tillage erosivity increases exponentially with tillage depth. Reducing tillage depth can therefore be considered as an effective soil conservation strategy. Tillage direction also has an important control on tillage erosivity: tillage along the contour lines is substantially less erosive than tillage conducted up and down the slope.

Until now, very little attention has been paid to the role of implement shape on tillage erosivity. Although tillage erosivity could be well described as a function of tillage speed, depth, direction and soil bulk density, the results of some experiments indicate that this may have an influence. For example, the $k_{t i l}$ values reported by (Quine and Zhang, 2004a) and (Heckrath et $\mathbf{a l . , 2 0 0 6 )}$ for mouldboard tillage is much lower than other values reported using similar implements with identical operational characteristics and soil conditions. It is possible that implement shape may have caused lower tillage erosivity in these specific cases.

$k_{t i l}$ values that are representative for whole crop cycle can be estimated by summing the individual $k_{t i l}$ values for the different implements used. For mechanize agriculture, values reported are in the order of $470-780 \mathrm{~kg} \mathrm{~m}^{-1}$ year $^{-1}$. The lower end of cro rotation tillage transport coefficients estimates for non-mechanized agriculture are generally lower, ie, $68-260 \mathrm{~kg} \mathrm{~m}^{-1}$ year-1. However, $k_{t i l}$ values, reported for intensive cropping systems with a high frequency of tillage operations are in the same order of magnitude as those associated with mechanized agriculture.

Tillage erosion rates reported in literature indicate that this process significantly contributes to the removal and redistribution of topsoil on rolling arable land. Direct comparison of tillage erosion with water erosion rates for a data set covering the whole world indicates that tillage erosion rates are at least in the same order of magnitude or higher than water erosion rates, in almost all cases. It is worthwhile to compare the assessment of tillage erosion with estimates of water erosion intensity. Most available statistics on the extent and severity of soil erosion on arable land are unreliable (Boardman, 1998). This large uncertainty must be attributed to the high spatial and temporal variability of the processes involved (climate, soil erodibility, connectivity between upland landscape elements and streams, landscape erodibility role of extreme events, etc), which hampers accurate measurements. In contast, tillage erosion 
estimates are only dependent on topographical complexity (ie, slope curvature) and tillage management (ie, tillage transport coefficient) and are therefore quite robust. In the previous paragraphs, we have shown that tillage erosivity assessments are very consistent and allow to estimate $k_{t i l}$ values with a relatively high precision.

Tillage erosion also has marked effects on soil quality: tillage will increase the spatial variation in soil properties and lead to a nutrientdepleted soil on convexities while a deep soil, enriched in nutrients, develops on concavities. This has important implications for dynamic processes such as soil organic carbon (SOC) and nitrogen turnover and storage in soils. With the progressive accumulation of nutrient-rich soil in low-lying areas of fields exposed to concentrate overland fow and leaching the risk of nutrient loss is prone to increase. Soil redistribution by tillage also results in a substantial modification of the landscape topography, which has direct consequences for surface and subsurface hydrology (eg, variability of infiltration, overland flow paths...). Studies have also reported on the close linkages between tillage erosion and crop productivity. The data available in literature strongly suggests that he impact of tillage erosion on soil quality and productivity will vary with the agro-environment. Shallower soils on hummocky terrain in drier climates, where soil depth is an important factor, suffer more adverse effects than soils in moderate climates.

Considering the widespread use of tillage practices and the high redistribution rates associated with the process, it is clear that tillage erosion should be considered in soil landscape studies and when developing environmentally sustainable farming practices. Although we now have a basic understanding of the most important controls, the consequences of tillage erosion for soil profile evolution and soil nutrients dynamics requires more attention. The integration of models of soil redistribution and soil property evolution with models of soil nutrient cycling therefore represents a major challenge.

\section{References}

Aase, J.K. and Pikul, J.L. 1995: Terrace formation in crepping strips pretected by tall wheat grass barriers. Journal of Soil and Water Conservation 50, 110-12.

Bakker; M.M., Govers, G., Kosmas, C., Vanacker, V., Van Oost, K. and Rounsevell, M. 2005: S•il er $\bullet$ sien as a driver of land-use change. Agriculture Ecosystems and Environment 105, 467-81.

Basher, L.R. and Ross, C.W. 2002: Seil eresien rates under intensive vegetable preduction on clay leam, strøngly structured søils at Pukekøhe, New Zealand. Australian Journal f Soil Research 40, 947-61.

Bernard, C. and Laverdiere, M.R. 1992: Spatial Redistributien of Cs-137 and søil-er $\bullet$ sien on Orleans Island, Quebec. Canadian Journal of Soil Science 72, 543-54.

Boardman, J. 1998: An average seil eresien rate for Eurøe: myth or reality? Journal of Søil and Water Conservation 53, 46-50.

Cao, Y.Z., Coote, D.R., Rees, H.W., Wang, C. and Chow, T.L. 1994: Effects $\bullet$ intensive pøtat preduction on seil quality and yield at a benchmark site in New-Brunsivick. Seil and Tillage Research 29, 23-34.

Czyzyk, W. 1955: Przemieszczanie gleby ne zbeczu

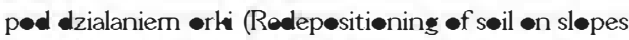
as a results of pleiving). Polish Agricultural Annual 71-F-1, 73-86.

da Silva, J.M., Soares, J.M.C.N. and Karlen, D.L. 2004: Implement and søil cøndition effects $\bullet$ tillageinduced eresion. Soil and Tillage Research 78, 207-16.

da Silva, J.R.M. and Alexandre, C. 2004: Seil carbenatiøn precesses as evidence of tillage-induced er $\bullet$ siøn. Sull and Tillage Research 78, 217-24.

Dabney, S.M., Liu, Z., Lane, M., Douglas, J., Zhu, J. and Flanagan, D.C. 1999: Landscape benching frem tillage er $\bullet$ siøn between grass hodges. Soil and Tillage Research 51, 219-31.

Daniels, R.B., Gilliam, J.W., Cassel, D.K. and Nelson, L.A. 1985: Søil-eresien class and landscape pesitiøn in the Nerth-Car lina Piedment. Søil Science Society of America Journal 49, 991-95.

de Alba, S. 2001: Modelling the effects of complex topøraphy and patterns of tillage en søil transleca-

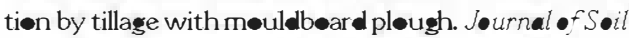
and Water Conservation 56, 335-45.

- 2003: Simulating long-tenn seil redistribution generated by lifferent patterns of mouldbeard ploughing in landscapes of complex tepøgraphy. Søil and Tillage Research 71, 71-86.

de Alba, S., Lindstrom, M., Schumacher, T.E. and Malo, D.D. 2004: S•il landscape evelutien due te søil redistribution by tillage: a new conceptual model of søil catena evelution in agricultural landscapes. Catena 58, 77-100.

Dejong, E., Begg, C.B.M. and Kachanoski, R.G. 1983: Estimates of søil-er $\bullet$ sion and depesition for søme Saskatchewan søils. Canadian Journal of Søil Science 63, 607-17. 
Dejong, E., Wang, C. and Rees, H.W. 1986: Seil rodistribution on 3 cultivated New-Brunsivick hillslepes calculated frem Cs-137 measurements, sølum data and the USLE. Caradian Journal of Søil Science $66,721-30$.

Dercon, G., Deckers, J., Govers, G., Poesen, J., Sanchez, H., Vanegas, R., Ramirez, M. and Loaiza, G. 2003: Spatial variability in søil prøperties -n slow-forming terraces in the Andes region of Ecuador. Soil and Tillage Research 72, 31-41.

Govers, G., Lobb, D.A. and Quine, T.A. 1999: Preface - tillage er esien and translecatiøn: emergence - f a new paradigm in søil eresion research. S•il and Tillage Research 51, 167-74.

Govers, G., Quine, T.A., Desmet, P.J.J. and Walling, D. E. 1996: The relative centribution of søil

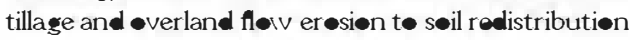
-n agricultural land. Earth Surface Processes and Land orms 21, 929-46.

Govers, G., Quine, T.A. and Walling, D.E. 1993: The effect $\bullet$ water er $\bullet$ siøn and tillage mevement $\bullet$ hills-

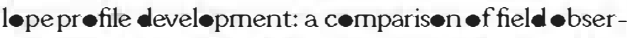
vations and model results. In Wicherek S., editer, Farm land erosion in temperate plains environments and hills, Amsterdam: Elsevier, 285-300.

Govers, G., Vandaele, K., Desmet, P., Poesen, J. and Bunte, K. 1994: The rele ftillage in s-il redistribution on hillslepes. European Journal of Søil Science 45, 469-78.

Guiresse, M. and Revel, J.C. 1995: Er $\bullet$ siønduet $\bullet$ cultivation of calcare us clay seils on hillsides in søuthwest France 2. Effect of ploughing doivn the steepest slope. Soil and Tillage Research 35, 157-66.

Heckrath, G., Djurhuus, J., Quine, T.A., Van Oost, K., Govers, G. and Zhang, Y. 2005: Tillage

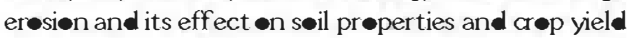
in Denmark. Journal of Environmental Quality 34, 312-24.

Heckrath, G., Halekoh, U., Djurhuus, J. and Govers, G. 2006: The effect of tillage direction -n seil redistribution by meuldbear ploughing en complex slopes. Soil and Tillage Research, in press.

Kachanoski, R.G., Rolston, D.E. and de Jong, E. 1985: Spatial variability of a cultivated seil as affected by past and present microtøgraphy. Søil Science Society f Americ Journal 49, 1082-87.

Kermis, L.H. 1978: A theretical appreach t highspeed plough design. Journal of Agricultural Engineering Research 23, 343-68.

Khachatryan, K.A. 1985: Operation of soil-working implements in hilly regions. Russian Translation Series n૯. 37. Retter dam: Balkerna.

Kiburys, B. 1989: Divezemi mechanine erøija (Vechanical soil erosion). Vilnius: Mokslas.

Kimaro, D.N., Deckers, J.A., Poesen, J., Kilasara, M. and Msanya, B.M. 2005: Short and medium tenn assessment of tillage eresion in the Uluguru
Mountains, Tanzania. Soil and Tillage Research 81, 97-108.

Kosmas, C., Gerontidis, S., Marathianou, M., Detsis, B., Zafiriou, T., Muysen, W.N., Govers, G., Quine, T. and Vanoost, K. 2001: The effects $\bullet$ tillage displaced søil en søil prøperties and wheat bi॰mass. Soil and Tillage Research 58, 31-44.

Lal, R. 2001: Seil degradation by eresien. Land Degradation and Development 12, 519-39.

Lewis, L.A. and Nyamulinda, V. 1996: The critical rele of human activities in land degradation in Rwanda. Land Degradation and Development 7, $47-55$.

Li, Y. and Lindstrom, M.J. 2001: Evaluating seil quality-seil redistribution relationship $\bullet$ terraces and

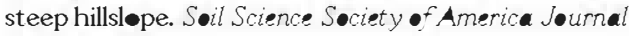
$65,1500-08$.

Li, Y., Tian, G., Lindstrom, M.J. and Bork, H.R. 2004: Variation of surface søil quality parameters by intensive donkey-drawn tillage on steep slope. Søil Science Seciety of America Journal 68, 907-13.

Lindstrom, M.J., Lobb, D.A. and Schumacher, T.E. 2001: Tillage eresien: an everview. Annals of Arid Zne 40, 337-49.

Lindstrom, M.J., Nelson, W.W. and Schumacher, T.E. 1992: Quantifying tillage eresion rates due t• moldbeard pleiving. Seil and Tillage Research 24, 243-55.

Lobb, D.A. and Kachanoski, R.G. 1999: Modelling tillage eresion in the topegraphically complex landscapes of søuthwestern Ontarie, Canada. Søil and Tillage Research 51, 261-77.

Lobb, D.A., Kachanoski, R.G. and Miller, M.H. 1995: Tillage translecation and tillage eresion on shoulder sløpe landscape pesitions measured using Cs-137 as a tracer. Canadian Journal of Soil Science 75, 211-18.

- 1999: Tillage translecation and tillage eresion in the cømplex upland landscapes of søuthwestern Ontariø, Canada. Soil and Tillage Research 51, 189-209.

Lobotka, V. 1955: Terasøé Pølia na Sløvensku

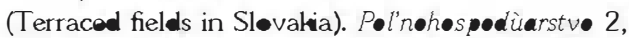
539-49.

Marshall, E.J.P. and Brain, P. 1999: The herizental møvement of seeds in arable søils by different cultivation methods. Journal f Applied Ecology 36, 443-54.

Marshall, E.J.P. and Hopkins, A. 1990: Plant species compesition and dispersal in agricultural land. In Bunce, R.G.H. and Heivard, D.C. editers, Species dispersal in agricultural habitats, Londen: Belhaven Press, 98-116.

Martini, Z. 2005: Badania przemieszezen gleby przy -rce na zbøezach (Studies on søil mevernent during the ploving of slopes). Polish Agricultural Annual 66-C-2, 97-123.

McRae, T., Smith, C.A.S. and Gregorich, L.J. 2000: Environmental sustainability of Canadian agriculture: 
report of the Agri-Environmental Indicator Project. Ottawa: Agriculture and Agri-Feed Canada.

Mech, S.J. and Free, G.A. 1942: Mevernent of seil during tillage operations. Agricultural Engineering 23, 379-82.

Miller, M.P., Singer, M.J. and Nielsen, D.R. 1988: Spatial variability of wheat yield and seil properties on complex hills. Soil Science Society of America Journal 52, $1133-41$.

Montgomery, J.A., Busacca, A.J., Frazier, B.E. and Mccool, D.K. 1997: Evaluating seil mevernent using Cesium-137 and the revised universal seil less equation. Soil Science Society of America Journal 61 , 571-79.

Montgomery, J.A., Mccool, D.K., Busacca, A.J. and Frazier, B.E. 1999: Quantifying tillage translecation and deposition rates due to moldbeard plowing in the Palouse region of the Pacific Nerthwest, USA. Soil and Tillage Research 51, 175-87.

Moulin, A.P., Anderson, D.A. and Mellinger, M. 1994: Spatial variability of wheat yield, seil preperties and eresion in hummocky terrain. Canadian Journal - f Sil Science 74, 219-28.

Nyssen, J., Haile, M., Poesen, J., Deckers, J. and Moeyersons, J. 2001: Remøval of røck fragments and its effect $\bullet$ s søil løss and crøp yield, Tigray, Ethiepia. Soil Use and Varagement 17, 179-87.

Nyssen, J., Poesen, J., Haile, M., Moeyersons, J.

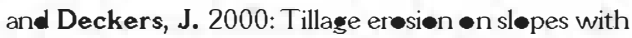
søil conservation structures in the Ethiøpian highlands. Soil and Tillage Research 57, 115-27.

Papendick, R.I. and Miller, D.E. 1977: Conservation tillage in the Pacific Northwest. Journal of Søil and Water Conservation 32, 49-56.

Petersen, D. 1960: Møvement $\bullet$ f seil uphill and dounhill by a meldbeard plow eperating $\bullet$ the conteur $\bullet$ n variøus sløpes. Unpublished Msc thesis; University $\bullet$ Minnesøta, USA.

Poesen, J., van Wesemael, B., Govers, G., Martinez-Fernandez, J., Desmet, P., Vandaele, K., Quine, T. and Degraer, G. 1997: Patterns •f røck fragment cøver generated by tillage er $\bullet$ siøn. Geomor hology 18, 183-97.

Quine, T.A. 1999: Use of caesium-137 data for validation of spatially distributed eresien mødels: the implicatiens $\bullet$ f tillage er sien. Caten 37, 415-30.

Quine, T:A. and Walling, D.E. 1991: Rates $\bullet$ søil-ersien $\bullet n$ arable fields in Britain - quantitative lata frem cesium-137 measurements. Søil Use and Maragement 7, 169-76.

Quine, T.A. and Zhang, Y. 2002: An investigation of spatial variation in søil erøsiøn, søil prøperties, and crøp preduction within an agricultural field in Deven, United Kingdem. Journal of Søil and Water Conservation 57, 55-65.

- 2004a: Re-defiring tillage eresion: quantifyingintensitydirection relationships for complex terrain. I.
Derivation of an adirectiønal søil transpert ceefficient. Søil Use and Management 20, 114-23.

- 2004b: Re-defining tillage eresien: quantifying intensity-direction relationships for complex terrain.

I. Derivation of an adirectional søil transpert cøefficient. Seil Use and Management 20, 114-23.

- 2004c: Re-defining tillage er $\bullet$ siøn: quantifying intensity-direction relationships for complex terrain. 2. Revised mouldbeard eresion model. Soil Use and Vanagement 20, 124-32.

Quine, T.A., Basher, L.R. and Nicholas, A.P. 2003: Tillage eresion intensity in the South Canterbury Downlands, New Zealand. Australian Journal • S S il Research 41, 789-807.

Quine, T.A., Desmet, P., Govers, G., Vandaele, K. and Walling, D. 1994: A cømparisøn $\bullet$ the reles $\bullet$ tillage and water eresion in landfonm develøpment and sediment expert on agricultural land, near Leuven, Belgium. In Olive, L.J., Løughvan, R.J. and Kesby, J.A., editors, Proceedings of the IAHS Symposium on Variability in Stream Erosion and Sediment Transport, Canberra, December 1994, IAHS Publication 224, 77-86.

Quine, T.A., Govers, G., Poesen, J., Walling, D., van Wesemael, B. and Martinez-Fernandez, J. 1999a: Fine-earth translecation by tillage in steny søils in the Guadalentin, søuth-east Spain: an investigation using caesium-134. Soil and Tillage Research 51, 279-301.

Quine, T.A., Govers, G., Walling, D.E., Zhang, X.B., Desmet, P.J.J., Zhang, Y.S. and Vandaele, K. 1997: Erøsiøn precesses and landføn evelution on agricultural land - new perspectives frøm caesium-137 measurements and tøpegraphicbased eresion modelling. Earth Surface Processes and Landorms 22, 799-816.

Quine, T.A., Walling, D.E., Chakela, Q.K., Mandiringana, O.T. and Zhang, X. 1999b: Rates and patterns of tillage and water eresion on terraces and contour strips: evidence frøm caesium-137 measurements. Caten 36, 115-42.

Quine, T.A., Walling, D.E. and Govers, G. 1996: Simulation -f radiecaesium redistribution •n cultivated hillslepes using a mass-balance model: an aid t• precess interpretation and eresien rate estimatien. In Andersen, M.G. and Brøoks, S.M., editer, Advances in hillslope precesses, Chichester: Wiley, 561-88.

Quine, T.A., Walling, D.E. and Zhang, X. 1999c:

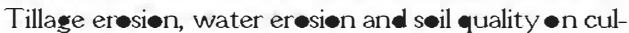
tivated terraces near Xifeng in the Leess Plateau, China. Land Degradation and Development 10 , 251-74.

Reaves, C.A. and Schafer, R.L. 1975: Ferce versus width of cut for meldbeard bottems. Transactions of the Asue 18, 852-54.

Revel, J.C. and Guiresse, M. 1995: Erøsiøn duet cultivation - f calcareus clay søils on the hillsides of 
søuth west France. I. Effect of former farming practices. Seil and Tillage Research 35, 147-55.

Reynolds, P.J. 1988: Sherd mevernent in the ploughzonephysical data base inte cemputer simulation. In Rahtz, S.P. ., editor, Computer applications anduantitative methods in archaedogy, Oxford: British Archaeølegical Repert, Internatiønal Series, 201-19.

Rymshaw, E., Walter, M.F. and Van Wambeke, A. 1997: Prøcesses of søil mevernent on steep cultivated hill slopes in the Venezuelan Andes. Soil and Tillage Research 44, 265-72.

Schoorl, J.M., Boix Fayos, C., de Meijere, R.J., van der Graaf; E.R. and Veldkamp, A. 2004: The Cs137 technique applied t steep Mediterranean sløpes (Part II): landscape evelution and medel calibration. Catena 57, 35-54.

Schuller, P., Ellies, A., Castillo, A. and Salazar, I. 2003: Use ef $\mathrm{Cs}-137$ to estimate tillage- and waterinduced seil redistribution rates on agricultural land under different use and management in central-seuth Chile. Suil and Tillage Research 69, 69-83.

Schumacher, T.E., Lindstrom, M.J., Schumacher, J.A. and Lemme, G.D. 1999: Medeling spatial variation in preductivity due to tillage and water eresion. Seil and Tillage Research 51, 331-39.

Sibbesen, E. 1986: Søil mevernent in løng-tenn field experiments. Plant and Seil 91, 73-85.

Sibbesen, E. Andersen, C.E. 1985: Seil mevernent in løng-tenn field experiments as a result of cultivation

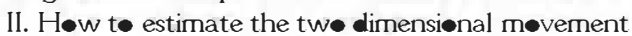
-f substances accumulating in the soil. Experimental Agriculture 21, 109-17.

Sibbesen, E., Andersen, C.E., Andersen, S. and Flensted-Jensen, M. 1985: Søil mevernent in lengtenn field experiments as a result of cultivation I. A medel for appreximating søil møvernent in øne hørizental dimension by repeated tillage. Experimental Agriculture 21, 101-107.

Sibbesen, E., Skjoth, F. and Rubaek, G.H. 2000: Tillage caused dispersion of phesphorus and søil in four 16-year eld field experiments. Soil and Tillage Research 54, 91-100.

Soileau, J.M., Hajek, B.F and Touchton, J.T. 1990: Søil-eresion and depesition evidence in a small water-

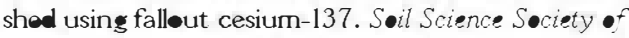
America Journal 54, 1712-19.

St Gerontidis, D.V., Kosmas, C., Detsis, B., Marathianou, M., Zafirious, T. and Tsara, M. 200I: The effect of meldbeard plew on tillage er $\bullet$ along a hillslepe. Journal of Soil and Water Censervation 56, 147-52.

Staricka, J.A., Allmaras, R.R. and Nelson, W.W. 1991: Spatial variation in crep residue incerperated by tillage. Søil Science Søciety -f America Journal 55, 1668-74.

Staricka, J.A., Burford, P.M., Allmaras, R.R. and Nelson, W.W. 1990: Tracing the vertical distribution
- f simulated shattered seeds as related to tillage. Agronøy Journal 82, 1131-34.

Thapa, B.B., Casse1, D.K. and Garrity, D.P. 1999a: Assessment of tillage eresion rates $\bullet$ steepland Oxisøls in the humid trøpics using granite recks. S•it and Tillage Research 51, 233-43.

- 1999b: Ridge tillage and contour natural grass barrier strips reduce tillage eresion. Suil and Tillage Research 51, 341-56.

- 200I: Animal powered tillage translecated seil affects nutrient dynamics and soil properties at Claveria, Philippines. Journal of Soil and Water Conservation $56,14-21$.

Tsara, M., Gerontidis, S., Marathianou, M. and Kosmas, C. 2001: The long-tenn effect of tillage on søil displacement of hilly areas used for greving wheat in Greece. Soil Use and Management 17, 113-20.

Turkelboom, F., Poesen, J., Ohler, I. and Ongprasert, S. 1999: Reassessment of tillage ersion rates by manual tillage on steep slepes in nerthern Thailand. Seil and Tillage Research 51, 245-59.

Turkelboom, F., Poesen, J., Ohler, I., Van Keer, K., Ongprasert, S. and Vlassak, K. 1997: Assessment - f tillage eresion rates $\bullet$ steep sløpes in nørthern Thailand. Caten 29, 29-44.

Van Muysen, W. and Govers, G. 2002: S•il displacement and tillage eresien during secendary tillage -perations: the case of retary harrow and seeding equipment. Soil and Tillage Research 65, 185-91.

Van Muysen, W., Govers, G., Bergkamp, G., Roxo, M. and Poesen, J. 1999: Measurement and medelling of the effects of initial søil conditions and slepe gradient on seil translecation by tillage. S•il and Tillage Research 51, 303-16.

Van Muysen, W., Govers, G. and Van Oost, K. 2002: Identification of impertant facters in the

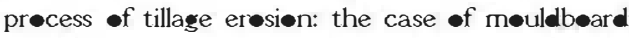
tillage. Soil and Tillage Research 65, 77-93.

Van Muysen, W., Govers, G., Van Oost, K. andVan Rompaey, A. 2000: The effect of tillage depth, tillage speed, and søil condition $\bullet$ chisel tillage er $\bullet$ sivity. Journal of Søil and Water Conservation 55, 355-64.

Van Muysen, W., Van Oost, K. and Govers, G. 2006: S•il translecation resulting frem multiple passes

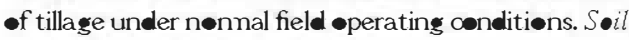
and Tillage Research, in press.

Van Oost, K., Govers, G. and Desmet, P. 2000a: Evaluating the effects of changes in landscape structure on seil eresion by water and tillage. Land scape Ecology 15, 577-89.

Van Oost, K., Govers, G. and Van Muysen, W. 2003a: A precess-based conversion medel for caesium-137 derived eresion rates on agricultural land: an integrated spatial appreach. Earth Surface Processes and Land forms 28, 187-207. 
Van Oost, K., Govers, G., Van Muysen, W. and Quine, T.A. 2000b: Medeling translecation and dispersion of seil censtituents by tillage en sleping land. Soil Science Society of America Journal 64, 1733-39.

Van Oost, K., Van Muysen, W., Govers, G., Heckrath, G., Quine, T.A. andPoesen, J. 2003b: Simulation of the redistribution of søil by tillage on

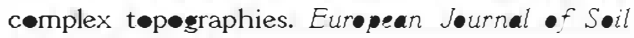
Science 54, 63-76.

Verity, G.E. and Anderson, D.W. 1990: Seil-eresien effects on seil quality and yield. Canadian Journal ef S•il Science 70, 471-84.

Weinblum, M. and Stekelmacher, S. 1963: Effects of tillage, implements, methods and slope on the downhill movement of soil on hillside terraces. Special Bulletin

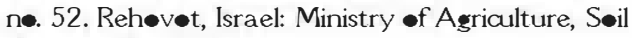
Censervation Division.
Yorston, R.M., Gaffney, V.L. and Reynolds, P.J. 1990: Simulation of artefact møvement due t• cultivation. Journal f Archaed•gical Science 17, 67-83.

Zhang, J.H., Frielinghaus, M., Tian, G. and Lobb, D.A. 2004a: Ridge and conteur tillage effects -n søil erøsion from steep hillst $\bullet$ pes-in the Sichuan Basin, China. Journal of Søil and Water Conservation 59, 277-84.

Zhang, J.H., Lobb, D.A., Li, Y. andLiu, G.C. 2004b: Assessment of tillage translecation and tillage eresien by heeing on the steep land in hilly areas of Sichuan, China. Sul and Tillage Research 75, 99-107.

Zhang, X., Quine, T.A. and Walling, D.E. 1998: Soil eresion rates on sleping cultivated land on the Leess Plateau near Ansai, Shaanxi Prevince, China: an investigation using $\mathrm{Cs}-137$ and rill measurements. Hydrological Processes 12, 171-89. 